\title{
Sodium fluoride induces renal inflammatory responses by activating NF-KB signaling pathway and reducing anti- inflammatory cytokine expression in mice
}

\author{
Qin Luo ${ }^{1}$, Hengmin Cui ${ }^{1,2}$, Huidan Deng ${ }^{1}$, Ping Kuang ${ }^{1}$, Huan Liu ${ }^{1}$, Yujiao Lu ${ }^{1}$, Jing \\ Fang $^{1,2}$, Zhicai Zuo ${ }^{1,2}$, Junliang Deng ${ }^{1,2}$, Yinglun $\mathrm{Li}^{1,2}$, Xun Wang ${ }^{1,2}$ and Ling Zhao ${ }^{1,2}$ \\ ${ }^{1}$ College of Veterinary Medicine, Sichuan Agricultural University, Wenjiang, Chengdu, China \\ 2 Key Laboratory of Animal Diseases and Environmental Hazards of Sichuan Province, Sichuan Agriculture University, \\ Wenjiang, Chengdu, China \\ Correspondence to: Hengmin Cui, email: cui580420@sicau.edu.cn
}

Keywords: sodium fluoride, inflammatory responses, NF-KB, anti-inflammatory cytokines, kidney, Immunology and Microbiology Section, Immune response, Immunity

Received: April 28, $2017 \quad$ Accepted: June 20, $2017 \quad$ Published: July 05, 2017

Copyright: Luo et al. This is an open-access article distributed under the terms of the Creative Commons Attribution License 3.0 (CC BY 3.0 ), which permits unrestricted use, distribution, and reproduction in any medium, provided the original author and source are credited.

\section{ABSTRACT}

Fluoride is widely distributed in the environment and often results in adverse health effects on animals and human beings. It has been proved that fluoride can induce inflammatory responses in vitro. However, very limited reports are focused on fluoride-induced inflammatory responses in vivo. In this study, mice were used to investigate sodium fluoride (NaF) induced renal inflammatory responses and the potential mechanism by using the methods of pathology, biochemistry, enzyme-linked immunosorbent assay (ELISA), quantitative real-time polymerase chain reaction (qRT-PCR) and western blot. A total of 240 ICR mice were randomly divided into four equal groups: the control group and three experimental groups ( $\mathrm{NaF}$ was given orally at the dose of $0,12,24$ and $48 \mathrm{mg} / \mathrm{kg}$ body weight for 42 days, respectively). The results showed that $\mathrm{NaF}$ in excess of $12 \mathrm{mg} / \mathrm{kg}$ induced the renal histopathological lesions, and inflammatory responses via the activation of nuclear factor-kappa B (NFKB) signaling pathway and the reduction of anti-inflammatory cytokines expression. The activation of NF-kB signaling pathway was characterized by increasing the nitric oxide (NO) and prostaglandin $E_{2}\left(P E_{2}\right)$ contents, inducible nitric oxide synthase (iNOS) activities and mRNA expression levels, and the mRNA and protein expression levels of cyclooxygenase-2 (COX-2), tumor necrosis factor-a (TNF-a), interleukin-1 $\beta$ (IL-1 $\beta$ ), interleukin-6 (IL-6) and interleukin-8 (IL-8) in three NaF-treated groups. Concurrently, the mRNA and protein expression levels of the anti-inflammatory cytokines including interleukin-4 (IL-4) and interleukin-10 (IL-10) were decreased in three experimental groups when compared with those in the control group.

\section{INTRODUCTION}

Fluoride in small quantity is necessary for normal formation of dental enamel and mineralization of bones [1, 2]. However, its excessive ingestion may lead to damages and pathological changes in many tissues and organs including kidney [3-26]. Functional disorder of the kidney has been considered as a consequence of fluorosis $[27,28]$ though its pathogenesis is not well understood at present.

For organisms, inflammation is not only a defensive response to resist the harmful stimulus, but also a healing process for repairing injured tissue $[29,30]$. It is well known that inflammation has many beneficial effects on animals and human beings. However, chronic or sustained inflammation is detrimental [31]. Inflammation can be triggered by a variety of inducers such as pathogens, damaged cells, or toxic compounds [20]. Previous studies have demonstrated that fluoride-caused testicular toxicity is associated with the inflammatory responses in mice [20, 21]. Gutowska et al. [32] has shown that even low levels of fluoride in differentiated human THP1 monocytes/ macrophages may alter activities of cyclooxygenase-1 
(COX-1) and cyclooxygenase-2 (COX-2), which involved in the initiation and development of inflammation. Ridley et al. [33] has also found that acute inflammatory responses may contribute to the subsequent development of fluoride-induced airway diseases. As the primary organ associated with excretion and retention of fluoride, kidney is very sensitive to the toxicity of fluoride [34]. However, there are no studies about fluoride-induced inflammatory responses in the kidney of animals and human beings up to now.

Nuclear factor-kappa B (NF- $\mathrm{B})$, as a transcription factor, involves in the inflammatory and immune responses via its ability to induce the expression of its downstream

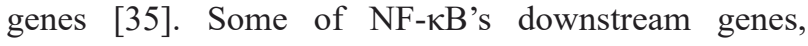
including inducible nitric oxide synthase (iNOS), COX-2, tumor necrosis factor- $\alpha$ (TNF- $\alpha$ ) and interleukin-1 $\beta$ (IL$1 \beta$ ), are closely correlated to inflammatory responses [1]. Tian et al. [36] has demonstrated that fluoride can regulate the mRNA expression of NF- $\kappa \mathrm{B}$, iNOS, TNF- $\alpha$ and IL- $1 \beta$ in mouse peritoneal macrophages. Yan et al. [37] has also reported that fluoride can induce the expression of TNF- $\alpha$, IL-1 $\beta$ and interleukin-6 (IL-6) in rat brain. In addition, De la Fuente et al. [38] has found that low levels of fluoride can decrease the expression of the anti-inflammatory cytokine interleukin-10 (IL-10) in murine macrophages. However, the effects of fluoride on NF- $\kappa \mathrm{B}$ activation and inflammatory mediators in the kidney of animals and human beings are unclearly at present.
In the present study, mice were used to explore how sodium fluoride $(\mathrm{NaF})$ induced renal inflammatory responses by measuring nitric oxide (NO) and prostaglandin $\mathrm{E}_{2}\left(\mathrm{PGE}_{2}\right)$ contents, iNOS activities and mRNA expression levels, NF- $\kappa \mathrm{B}$ mRNA expression levels, $\mathrm{p}-\mathrm{NF}-\kappa \mathrm{B}$ protein expression levels, as well as inhibitors of kappa B (I $\kappa$ B), COX-2, TNF- $\alpha$, IL-1 $\beta$, IL-6, interleukin-8 (IL-8), interleukin-4 (IL-4), IL-10 mRNA and protein expression levels with the methods of pathology, biochemistry, enzyme-linked immunosorbent assay (ELISA), quantitative real-time polymerase chain reaction (qRT-PCR) and western blot.

\section{RESULTS}

\section{Histopathological changes in the kidney}

Figures 1 and 2 showed that the degeneration and necrosis of the tubular cells, infiltration of inflammatory cells, swelled glomeruli as well as the renal tubular hyaline casts were observed in the NaF-treated groups. Also, the histopathological lesions induced by fluoride were changed in a dose- and time-dependent manner. The above lesions were not observed in the control group.

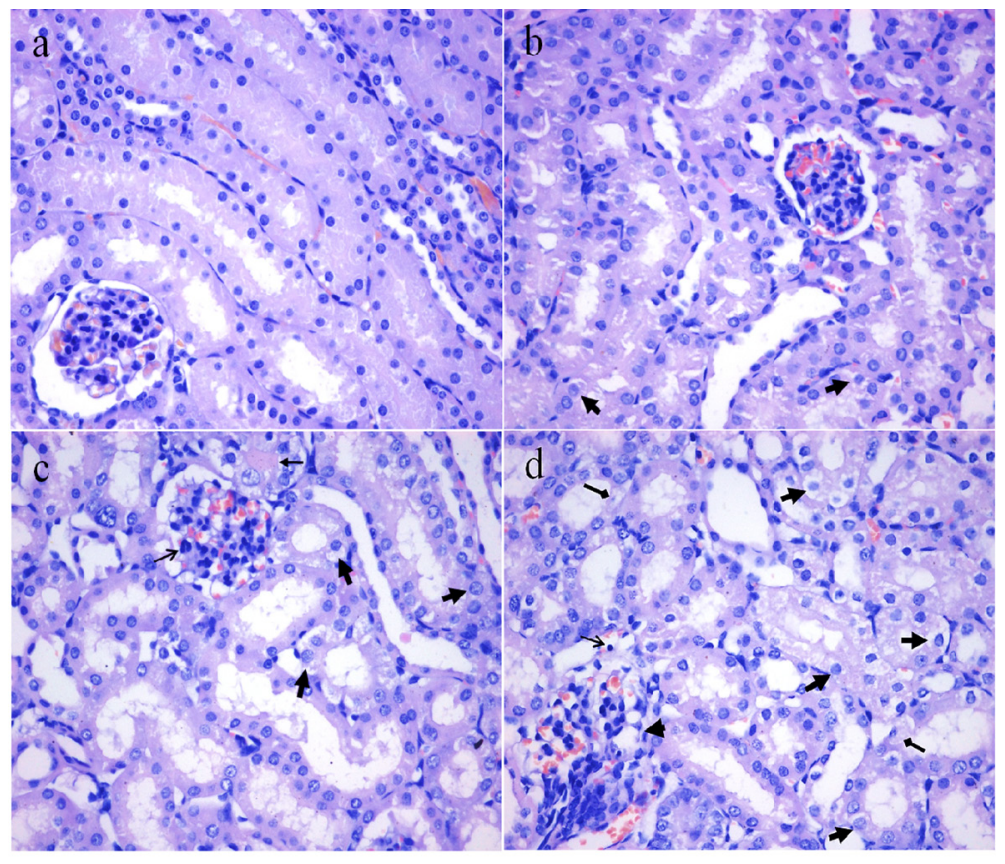

Figure 1: Histopathological changes in the kidney at 21 days of the experiment. a. The control group (H\&E $\times 400)$. b. The 12 $\mathrm{mg} / \mathrm{kg}$ group. Tubular cells show slightly granular and vacuolar degeneration ( , H\&E $\times 400$ ). c. The $24 \mathrm{mg} / \mathrm{kg}$ group. Tubular cells show granular and vacuolar degeneration ( ). The infiltration of inflammatory cells ( ) are observed (H\&E $\times 400)$. d. The $48 \mathrm{mg} / \mathrm{kg}$ group. Tubular cells show marked granular and vacuolar degeneration ( ). Also, necrotic tubular cells ( ), infiltration of inflammatory cells ( ) and swelled glomeruli without capsular space ( ) are observed $(\mathrm{H} \& \mathrm{E} \times 400)$. 


\section{Changes of mRNA and protein expression levels of NF- $\mathrm{NB}$ and $\mathrm{I} \kappa \mathrm{B}$ in the kidney}

The NF- $\mathrm{B}$ mRNA expression levels were increased $(p<0.05)$ in the $12 \mathrm{mg} / \mathrm{kg}$ group at 42 days of the experiment and were markedly increased ( $p<$ 0.01 ) in the 24 and $48 \mathrm{mg} / \mathrm{kg}$ groups at 21 and 42 days of the experiment in comparison with those in the control group, as shown in Figures 3a-3b. Figures 3c-3d showed that $\mathrm{p}-\mathrm{NF}-\mathrm{\kappa B}$ protein expression levels were significantly higher $(p<0.01)$ in the 12,24 and $48 \mathrm{mg} / \mathrm{kg}$ groups at 21 and 42 days of the experiment than those in the control group. The I $\mathrm{KB}$ mRNA and protein expression levels were lower $(p<0.01$ or $p<0.05)$ in the 24 and $48 \mathrm{mg} /$ $\mathrm{kg}$ groups at 21 and 42 days of the experiment than those in the control group. The results were shown in Figure 4.

\section{Changes of NO contents as well as iNOS activities and mRNA expression levels in the kidney}

Figure 5a showed that NO contents were enhanced $(p<0.05)$ in the $12 \mathrm{mg} / \mathrm{kg}$ groups at 42 days of the experiment and were significantly enhanced $(p<0.01)$ in the 24 and $48 \mathrm{mg} / \mathrm{kg}$ groups at 21 and 42 days of the experiment when compared with those in the control group. The activities and mRNA expression levels of iNOS were higher $(p<0.01)$ in the 24 and $48 \mathrm{mg} / \mathrm{kg}$ groups at 21 and 42 days of the experiment than those in the control group, as shown in Figures 5b-5d.

\section{Changes of $\mathrm{PGE}_{2}$ contents as well as $\mathrm{COX}-2$ mRNA and protein expression levels in the kidney}

As shown in Figure 6, the COX-2 mRNA and protein expression levels were significantly higher $(p<$

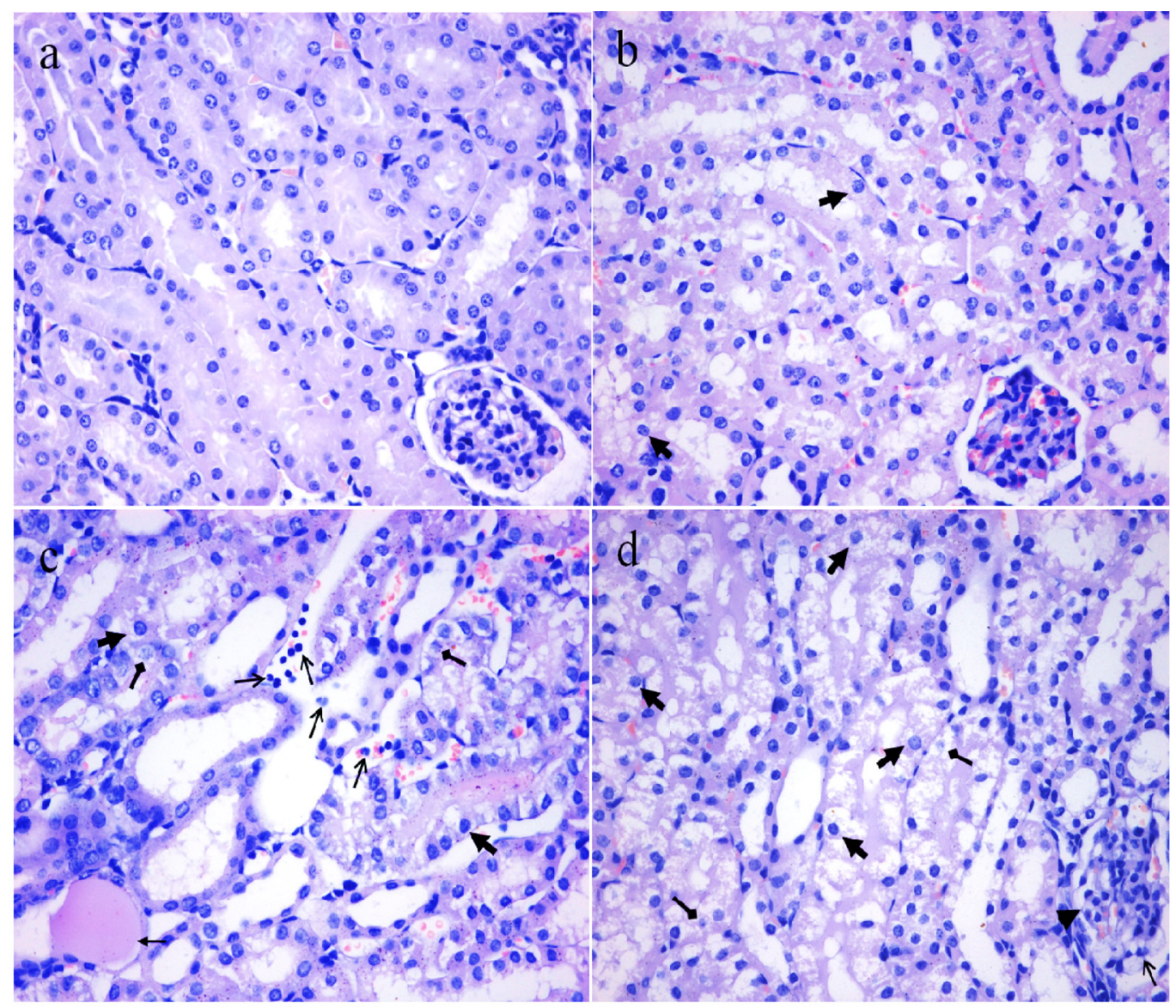

Figure 2: Histopathological changes in the kidney of mice at 42 days of the experiment. a. The control group (H\&E $\times 400)$. b. The $12 \mathrm{mg} / \mathrm{kg}$ group. Tubular cells show granular and vacuolar degeneration (, H\&E $\times 400$ ). c. The $24 \mathrm{mg} / \mathrm{kg}$ group. Tubular cells show marked granular and vacuolar degeneration ( ). Necrotic tubular cells ( ), renal tubular hyaline casts ( ) and infiltration of inflammatory cells ( ) are observed $(\mathrm{H} \& \mathrm{E} \times 400)$. d. The $48 \mathrm{mg} / \mathrm{kg}$ group. Tubular cells show marked granular and vacuolar degeneration ( ). Also, necrotic tubular cells ( ), infiltration of inflammatory cells ( ) and swelling glomeruli without capsular space ( ) are observed (H\&E $\times 400$ ). 
0.01 or $p<0.05$ ) in the 24 and $48 \mathrm{mg} / \mathrm{kg}$ groups at 21 and 42 days of the experiment than those in the control group. Figure 7 showed that $\mathrm{PGE}_{2}$ contents were markedly increased $(p<0.01$ or $p<0.05)$ in the 24 and $48 \mathrm{mg} / \mathrm{kg}$ groups at 21 and 42 days of the experiment in comparison with those in the control group.

\section{Changes of pro-inflammatory cytokines mRNA and protein expression levels in the kidney}

The results in Figures 8, 9, 10 and 11 showed that the mRNA and protein expression levels of TNF- $\alpha$, IL- $1 \beta$, IL-6 and IL-8 were markedly increased $(p<0.01$ or $p<$ 0.05 ) in the 24 and $48 \mathrm{mg} / \mathrm{kg}$ groups from 21 to 42 days of the experiment when compared with those in the control group.

- Control group

\section{a}

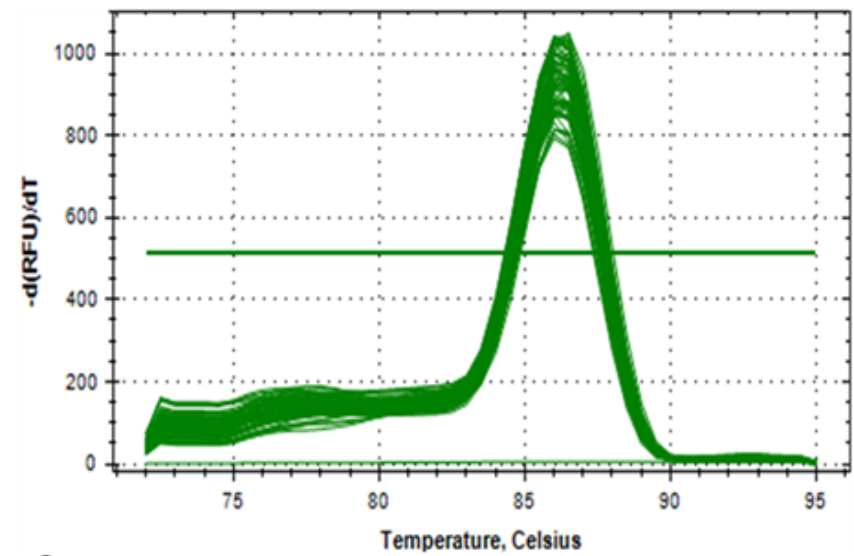

C

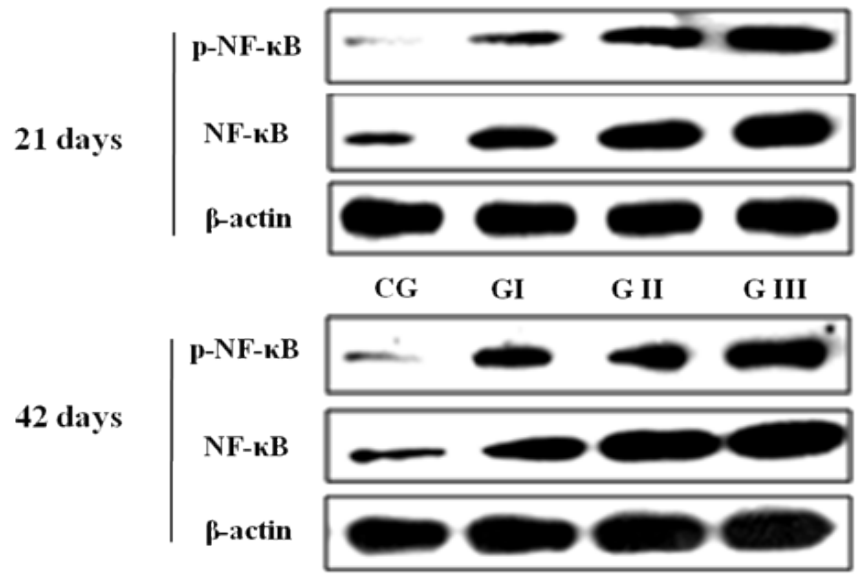

Changes of anti-inflammatory cytokines mRNA and protein expression levels in the kidney

The mRNA and protein expression levels of IL-4 and IL-10 were significantly reduced $(p<0.01$ or $p<$ 0.05 ) in the 24 and $48 \mathrm{mg} / \mathrm{kg}$ groups at 21 and 42 days of the experiment when compared with those in the control group. Also, the protein expression levels of IL-4 and IL-10 were lower $(p<0.01$ or $p<0.05)$ in the $12 \mathrm{mg}$ / $\mathrm{kg}$ groups at 42 days of the experiment than those in the control group. The results were shown in Figures 12 and 13.

\section{DISCUSSION}

Exposure to fluoride has been shown to induce inflammatory responses in lung epithelial cells [39], HeLa

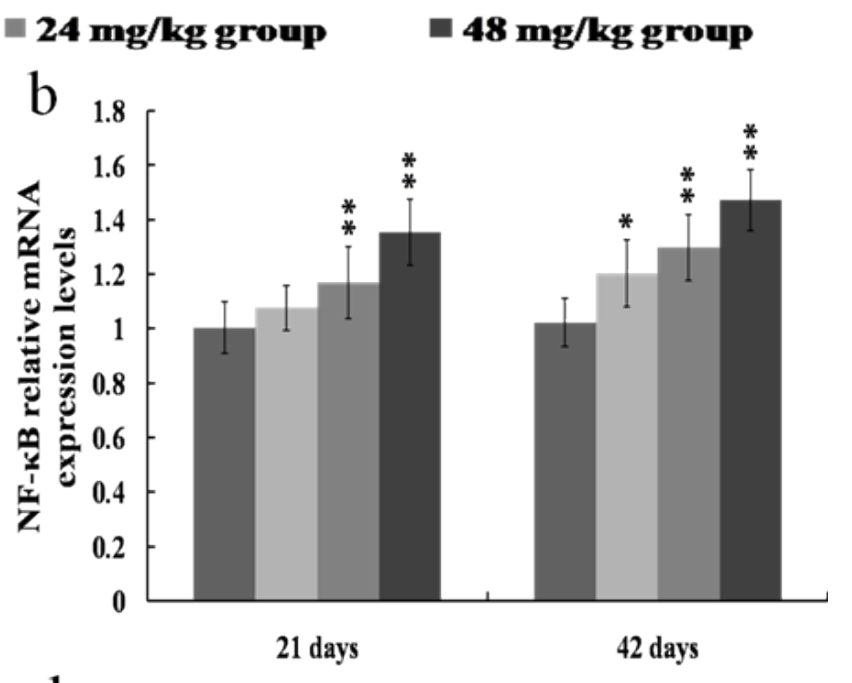

d

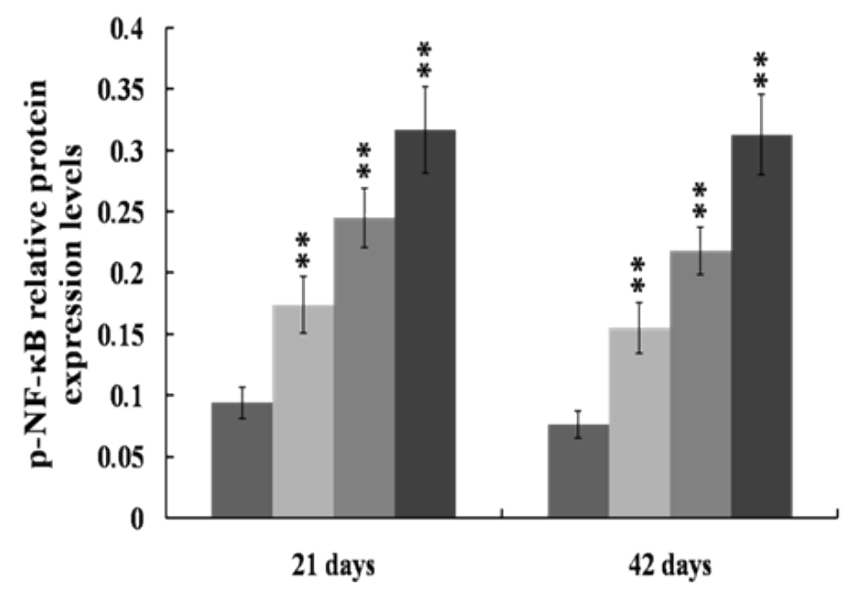

Figure 3: Changes of $m R N A$ and protein expression levels of NF- $\mathrm{B}$ in the kidney at 21 and 42 days of the experiment.

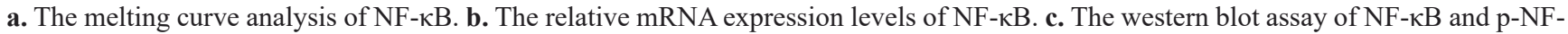
$\kappa B$. d. The relative protein expression levels of p-NF- $\kappa$ B. CG: Control group; GI: $12 \mathrm{mg} / \mathrm{kg}$ group; GII: $24 \mathrm{mg} / \mathrm{kg}$ group; GIII: $48 \mathrm{mg} / \mathrm{kg}$ group. Data are presented with the mean \pm standard deviation $(n=8),{ }^{*} p<0.05$, compared with the control group; ${ }^{* *} p<0.01$, compared with the control group. 
cells [40], THP1 differentiated monocytes/macrophages [32], peritoneal macrophages [36], aorta [16], neuron [37] and testicle [20, 21]. However, very limited reports are focused on fluoride-induced inflammatory responses in vivo. There are no studies about the effects of fluoride on renal inflammatory responses in animals and human beings at present. The aim of this study was to define the fluoride-induced inflammatory responses in the kidney. Indeed, we found considerable evidence that $\mathrm{NaF}$ in excess of $12 \mathrm{mg} / \mathrm{kg}$ induced the renal inflammatory responses in mice, which was supported by the findings: activation of NF- $\mathrm{NB}$ signaling pathway and reduction of anti-inflammatory cytokines expression.

$\mathrm{NF}-\kappa \mathrm{B}$ is a transcription factor that can integrate a complex network of extracellular perturbations and intracellular signaling pathways, leading to the transcriptional regulation of a wide variety of genes correlated to inflammation [41]. Under inactive state,

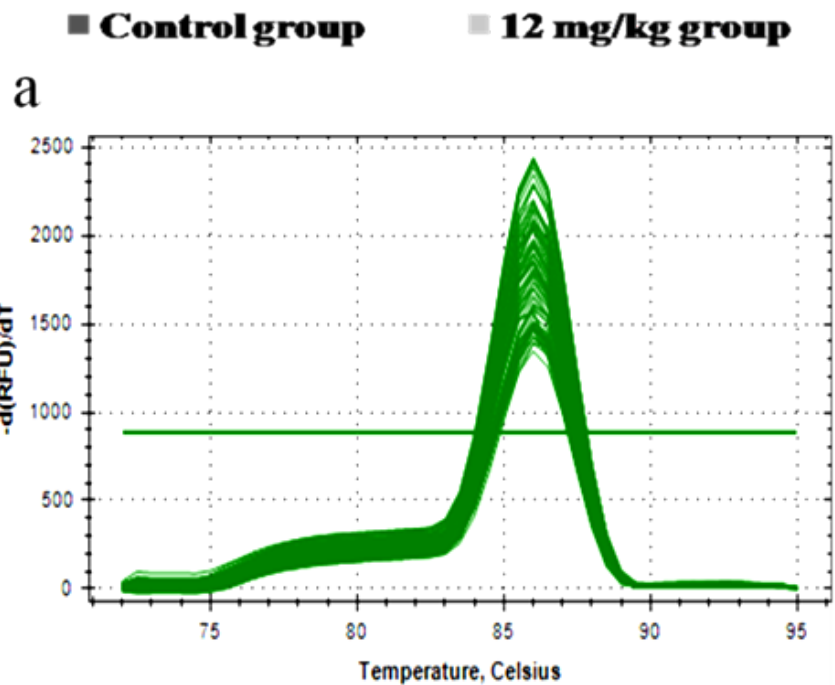

C

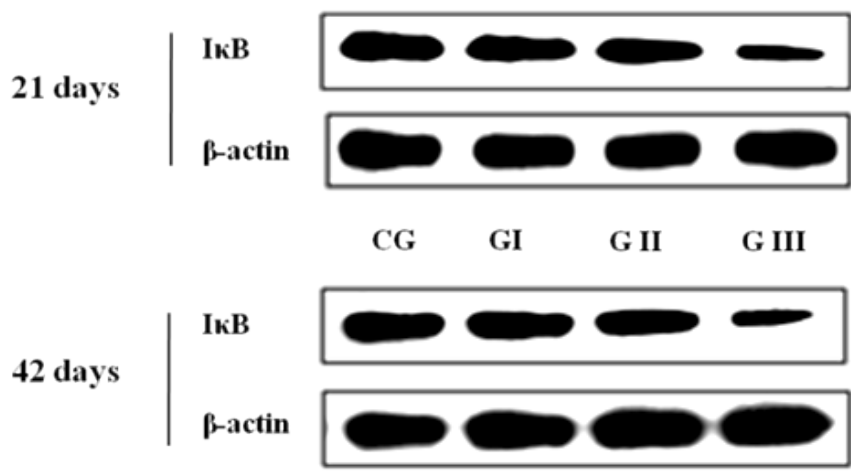

$\mathrm{NF}-\kappa \mathrm{B}$ exists in the cytoplasm, and is combined with

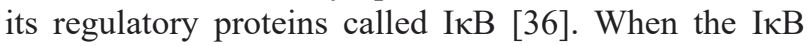
proteins are activated by some stimulus such as toxic compounds, pathogens, or pro-inflammatory cytokines, they are phosphorylated, ubiquitinated and subsequently degraded [42]. After I $\kappa$ B proteins degraded, NF- $\kappa$ B is dissociated from the cytoplasmic NF- $\kappa \mathrm{B}-\mathrm{I} \kappa \mathrm{B}$ complex, and translocates to the nucleus. Then NF- $\kappa \mathrm{B}$ binds to its cognate DNA binding sites to regulate the expression of corresponding pro-inflammatory genes [43]. In this study, the I $\kappa \mathrm{B}$ mRNA and protein expression levels were reduced, the NF- $\kappa \mathrm{B}$ mRNA expression levels and p-NF$\kappa \mathrm{B}$ protein expression levels were increased in the 24 and $48 \mathrm{mg} / \mathrm{kg}$ groups, demonstrating that $\mathrm{NaF}$-induced $\mathrm{I} \kappa \mathrm{B}$ degradation promoted the activation and translocation of $\mathrm{NF}-\kappa \mathrm{B}$.

Once $N F-\kappa B$ is activated, $N F-\kappa B$ then regulates the expression of a series of pro-inflammatory mediators,
= $24 \mathrm{mg} / \mathrm{kg}$ group $\quad 48 \mathrm{mg} / \mathrm{kg}$ group

b
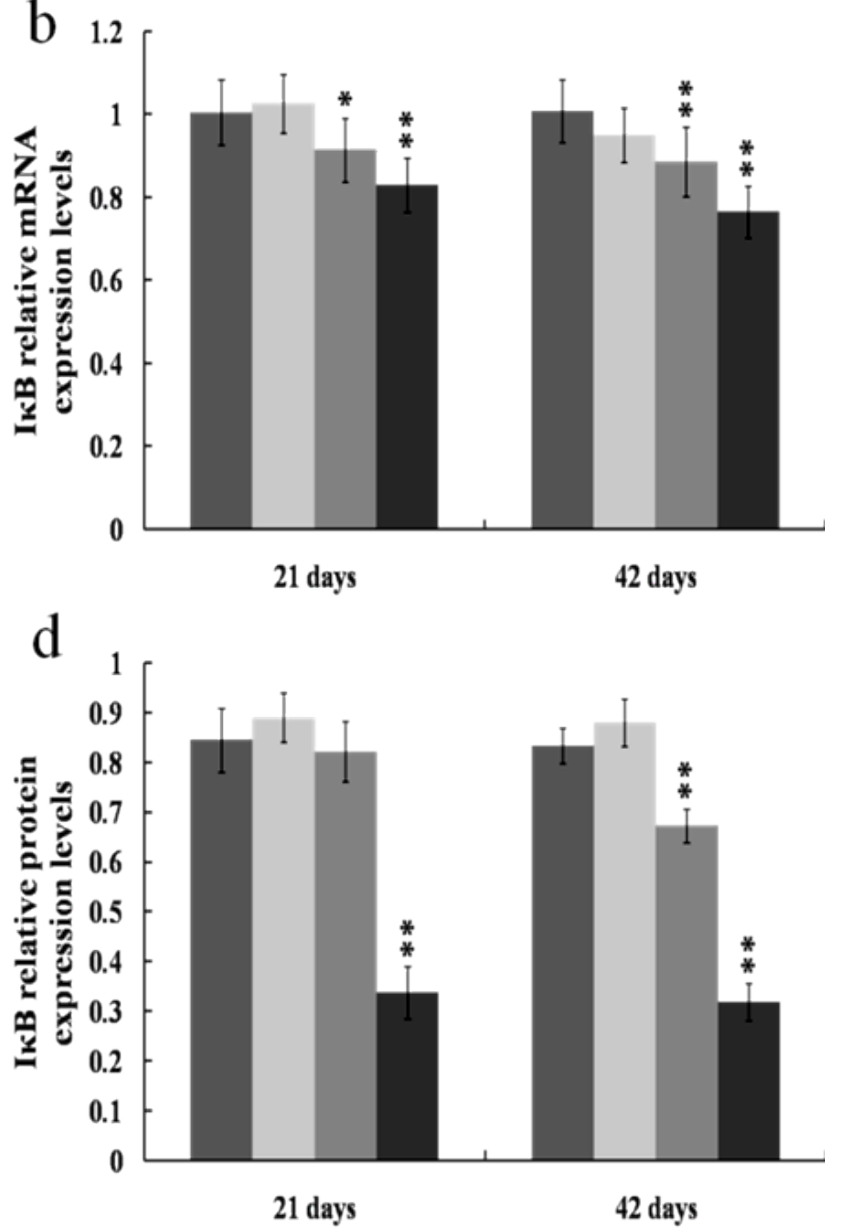

Figure 4: Changes of mRNA and protein expression levels of IKB in the kidney at 21 and 42 days of the experiment. a.

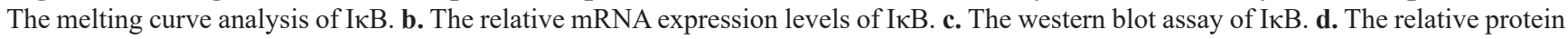
expression levels of IкB. CG: Control group; GI: $12 \mathrm{mg} / \mathrm{kg}$ group; GII: $24 \mathrm{mg} / \mathrm{kg}$ group; GIII: $48 \mathrm{mg} / \mathrm{kg}$ group. Data are presented with the mean \pm standard deviation $(n=8), * p<0.05$, compared with the control group; ${ }^{*} p<0.01$, compared with the control group. 
including iNOS, COX-2, TNF- $\alpha$, IL-1 $\beta$, IL-6 and IL-8 [43, 44]. Up-regulation of iNOS occurs mostly in association with the inflammation and infection as a part of defensive reaction [36]. Meanwhile, iNOS can catalyze the production of NO, and NO is known to participate in the inflammation responses by increasing the inflammatory cell infiltration and vascular permeability [20, 45, 46]. In the present study, we found that the NO contents as well as the iNOS activities and mRNA expression levels were significantly increased in the 24 and $48 \mathrm{mg}$ / $\mathrm{kg}$ groups, suggesting that $\mathrm{NaF}$ exposure induced the production of $\mathrm{NO}$ and $\mathrm{iNOS}$, and that the up-regulation in the transcriptional expression of iNOS was the possible reason of the increase in $\mathrm{NO}$ generation. COX-2, as an important inflammatory mediator, is a major contributor to the production of $\mathrm{PGE}_{2}$. $\mathrm{PGE}_{2}$ can recruit the inflammatory cells and accelerate the process of peripheral inflammation induced by noxious stimulus [47]. In this study, the mRNA

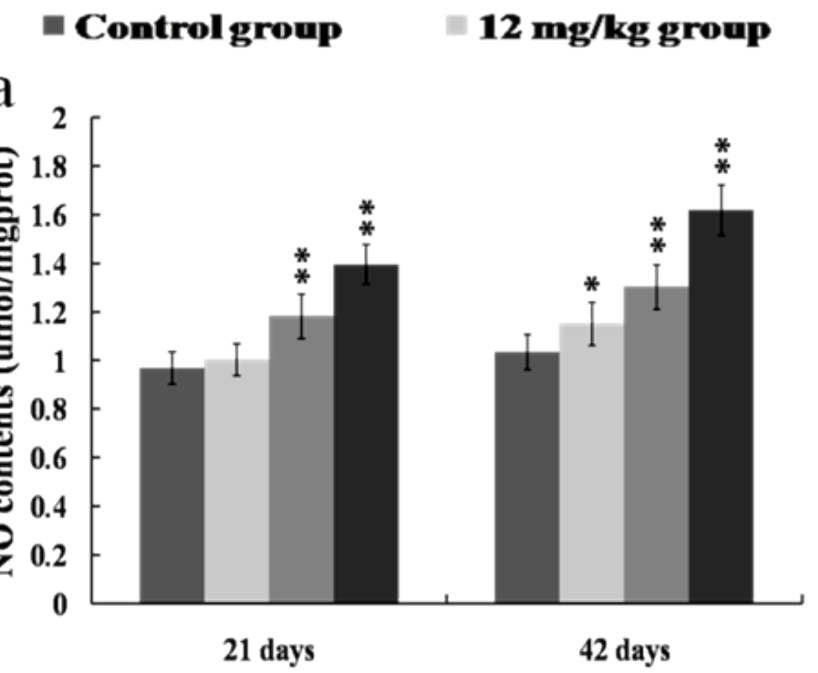

$\mathrm{C}$

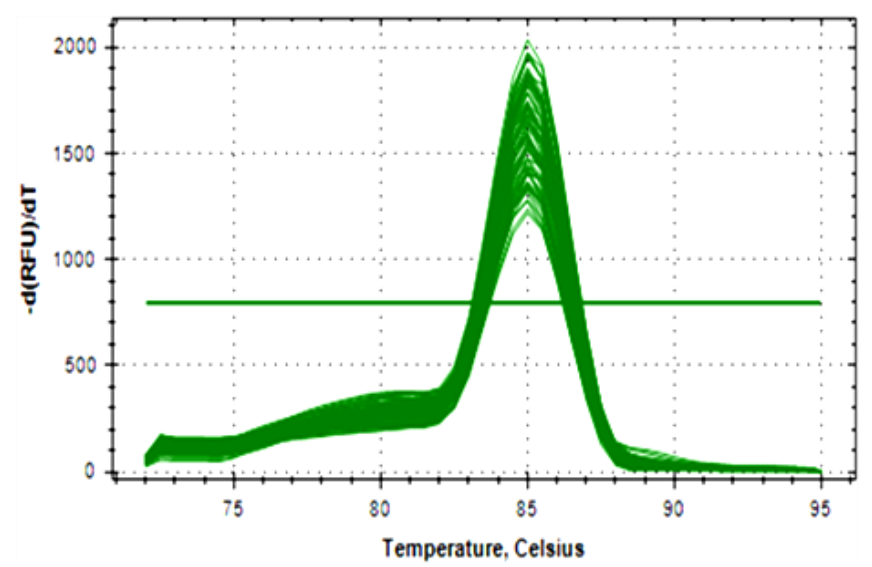

and protein expression levels of COX-2 were increased in the 24 and $48 \mathrm{mg} / \mathrm{kg}$ groups, and the $\mathrm{PGE}_{2}$ contents were also enhanced in the 24 and $48 \mathrm{mg} / \mathrm{kg}$ groups, which suggested that $\mathrm{NaF}$ induced the production of COX-2 and $\mathrm{PGE}_{2}$, and the $\mathrm{PGE}_{2}$ production in response to $\mathrm{NaF}$ exposure in the kidney was dependent on the upregulation of COX-2 expression. Also, our results are consistent with the report that fluoride can increase the COX-2 expression and $\mathrm{PGE}_{2}$ production in A549 human pulmonary epithelial cells [33]. Other pro-inflammatory cytokines such as TNF- $\alpha$, IL- $1 \beta$ and IL- 6 have been shown to play an important role in cell signaling and systemic inflammation [48]. These cytokines are predominantly produced by activated monocytes/macrophages and $\mathrm{T}$ cells, and are involved in the up-regulation of inflammatory responses $[18,49]$. Moreover, the cytokine IL- 8 can recruit neutrophils and lymphocytes to the sites of infection or injury in inflammation responses [39]. In
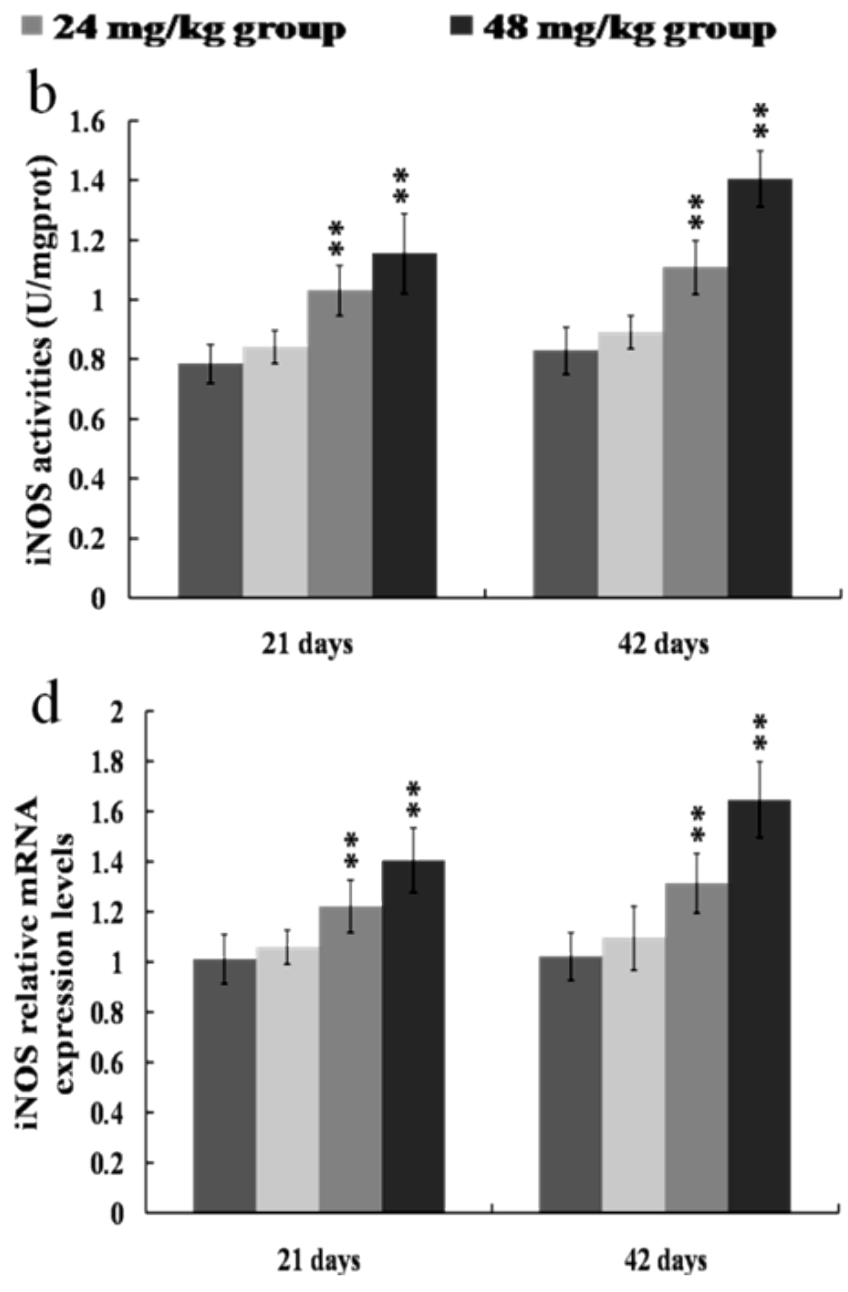

Figure 5: Changes of NO contents as well as iNOS activities and mRNA expression levels in the kidney at 21 and 42 days of the experiment. a. The NO contents in the kidney. b. The iNOS activities in the kidney. c. The melting curve analysis of iNOS. d. The relative mRNA expression levels of iNOS. CG: Control group; GI: $12 \mathrm{mg} / \mathrm{kg}$ group; GII: $24 \mathrm{mg} / \mathrm{kg}$ group; GIII: $48 \mathrm{mg} / \mathrm{kg}$ group. Data are presented with the mean \pm standard deviation $(n=8)$. ${ }^{*} p<0.05$, compared with the control group; $* * p 0.01$, compared with the control group. 
- Control group

a

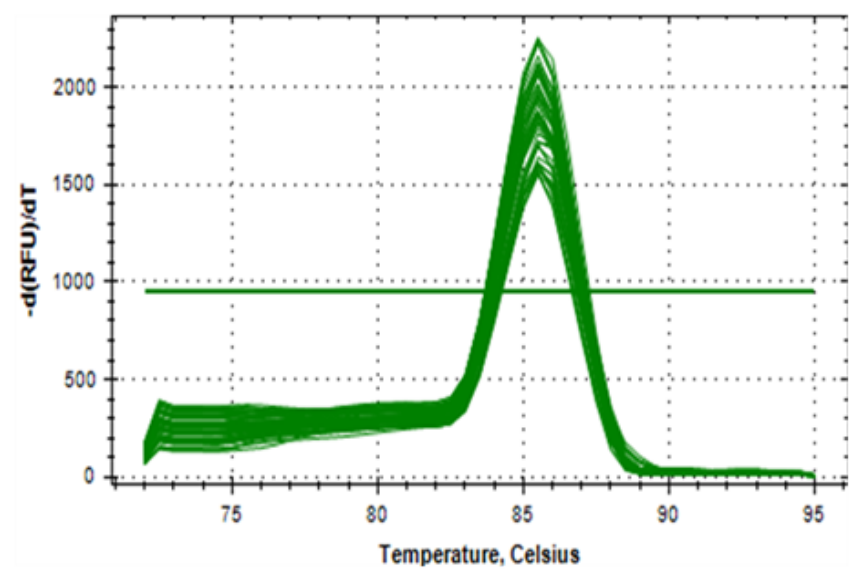

C
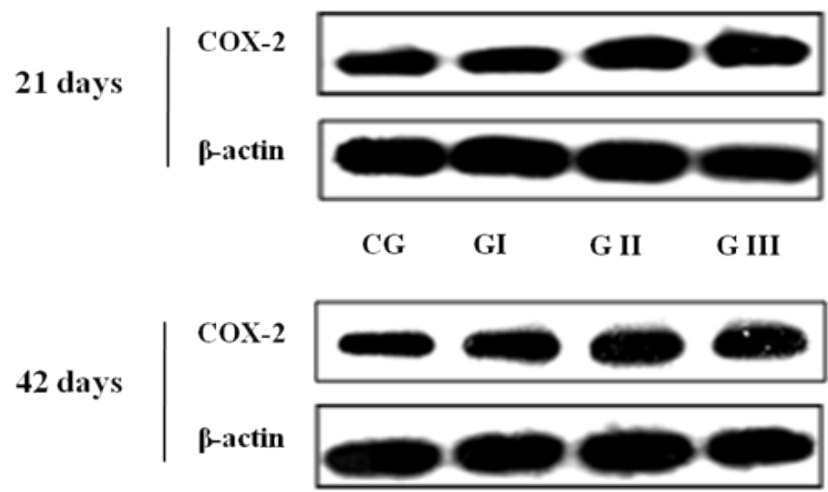

= $24 \mathrm{mg} / \mathrm{kg}$ group

b
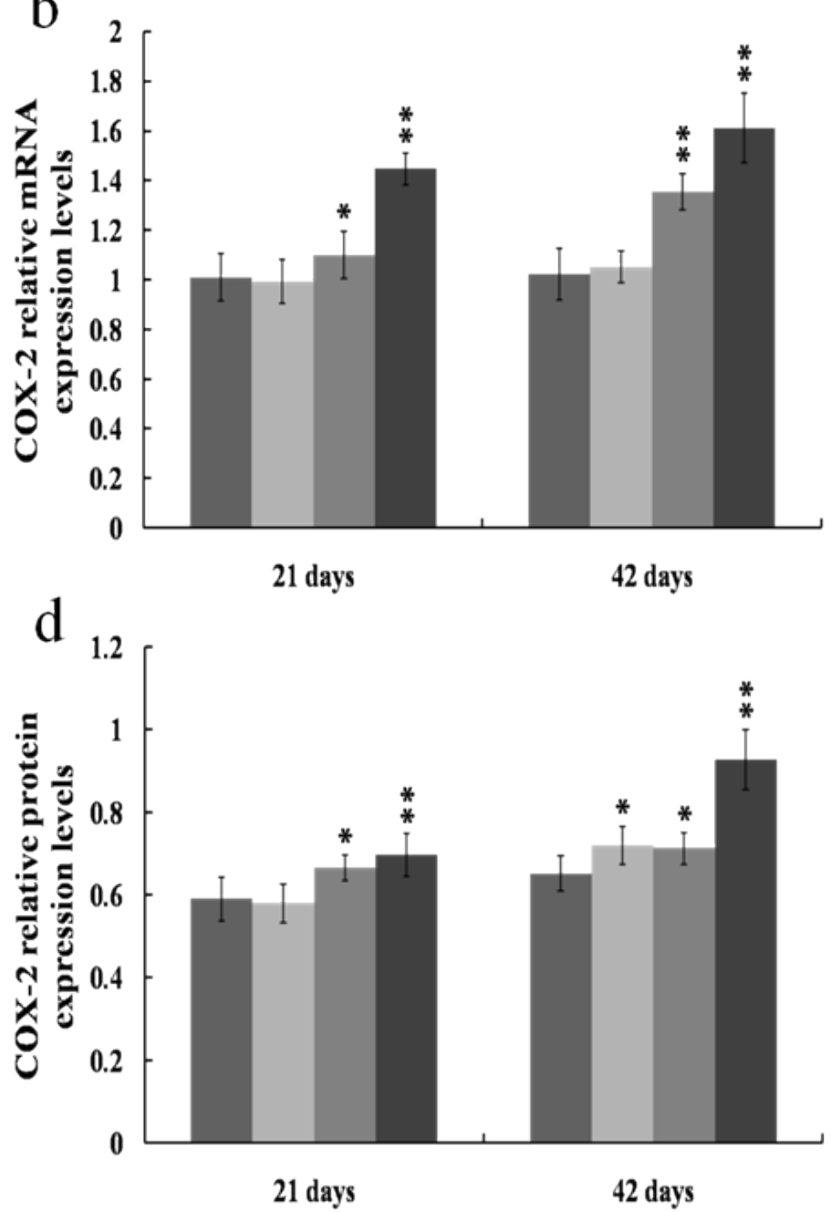

Figure 6: Changes of mRNA and protein expression levels of COX-2 in the kidney at 21 and 42 days of the experiment. a. The melting curve analysis of COX-2. b. The relative mRNA expression levels of COX-2. c. The western blot assay of COX-2. d. The relative protein expression levels of COX-2. CG: Control group; GI: $12 \mathrm{mg} / \mathrm{kg}$ group; GII: $24 \mathrm{mg} / \mathrm{kg}$ group; GIII: $48 \mathrm{mg} / \mathrm{kg}$ group. Data are presented with the mean \pm standard deviation $(n=8) .{ }^{*} p<0.05$, compared with the control group; ${ }^{* *} p<0.01$, compared with the control group.

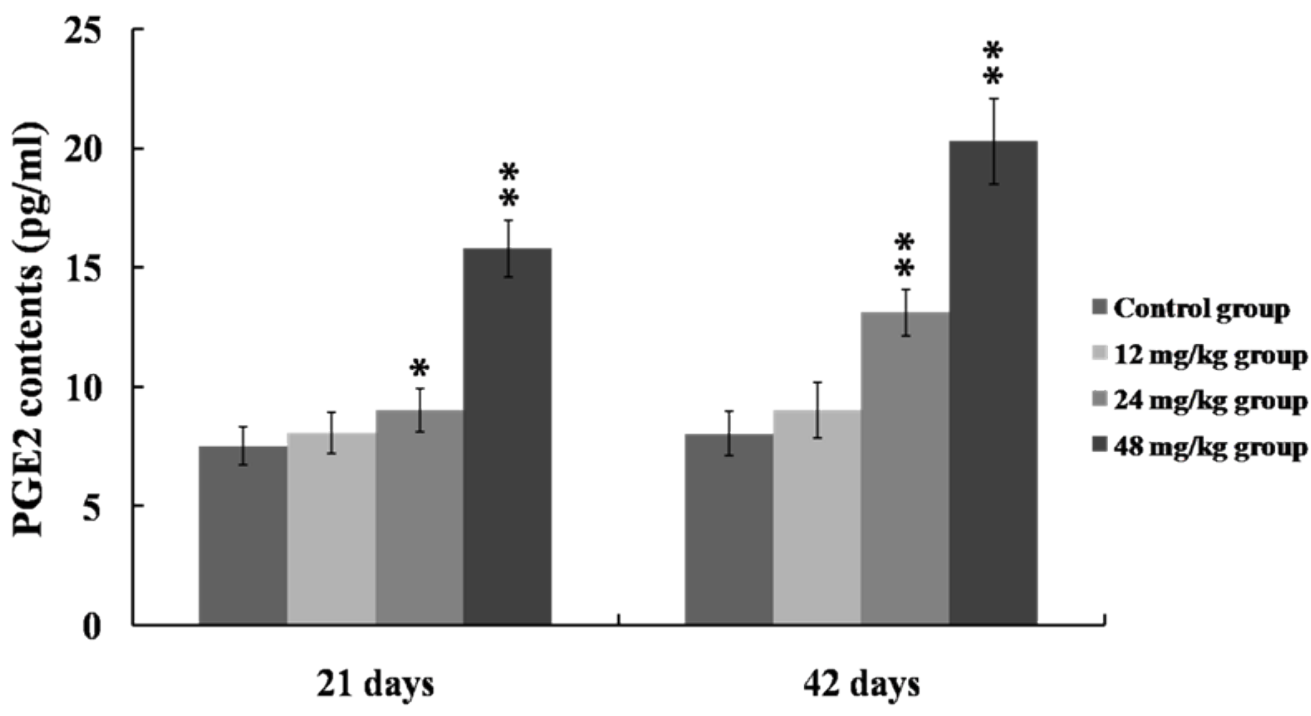

Figure 7: Changes of $\mathrm{PGE}_{2}$ contents in the kidney at 21 and $\mathbf{4 2}$ days of the experiment. Data are presented with the mean \pm standard deviation $(n=8) .{ }^{*} p<0.05$, compared with the control group; ${ }^{* *} p<0.01$, compared with the control group. 
the present study, the mRNA and protein expression levels of pro-inflammatory cytokines including TNF- $\alpha$, IL- $1 \beta$, IL-6 and IL- 8 were markedly increased in the 24 and 48 $\mathrm{mg} / \mathrm{kg}$ groups. The above-mentioned results demonstrated that $\mathrm{NaF}$ in excess of $12 \mathrm{mg} / \mathrm{kg}$ can activate the $\mathrm{NF}-\kappa \mathrm{B}$ signaling pathway, and the activation of $N F-\kappa B$ signaling pathway is one of the pathways of $\mathrm{NaF}$-induced renal inflammatory responses in mice.

As main anti-inflammatory cytokines, IL-4 and IL-10 are supposed to inhibit the detrimental effects of local pro-inflammatory responses $[50,51]$. In this study, the mRNA and protein expression levels of IL-4 and IL-10 were reduced in the 12,24 and $48 \mathrm{mg} / \mathrm{kg}$ groups, which contribute to occurrence of the renal inflammatory responses. And the reduction of IL-4 and IL-10 mRNA and protein expression levels may weakens their inhibiting effects on the production of pro-inflammatory mediators. The results are also consistent with the our previous

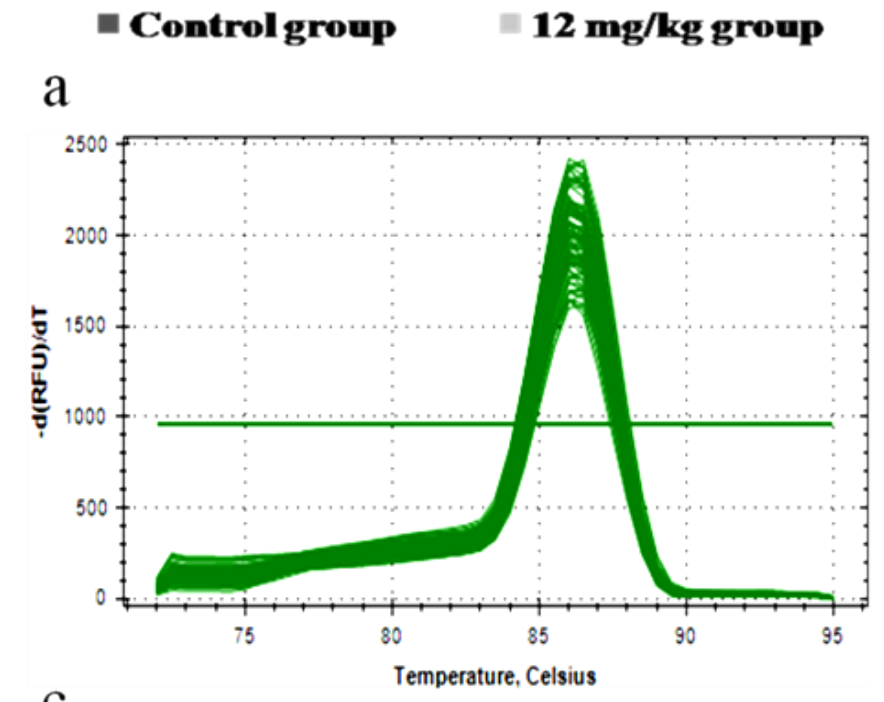

C

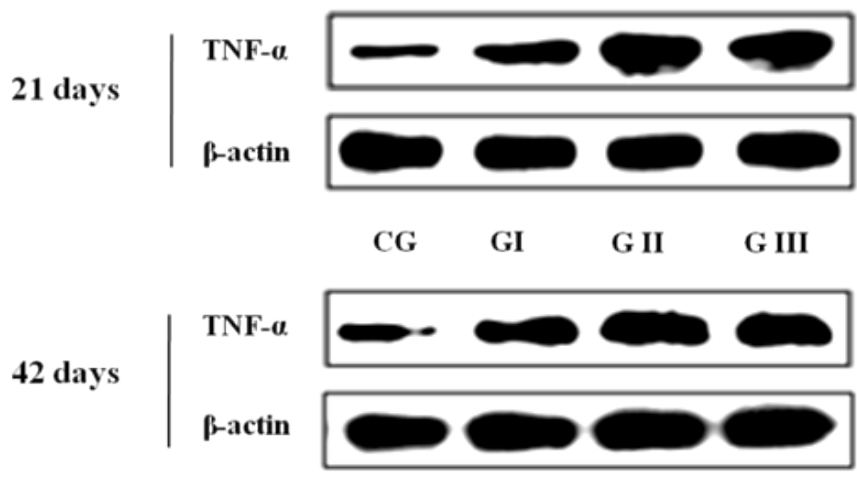

reports that fluoride can decrease IL-4 contents in broiler's serum [52], cecal tonsil [53] and intestinal mucosa [18].

Imbalance between pro-inflammatory and antiinflammatory mediators induces the renal inflammatory responses, which can result in renal histopathological lesions. Indeed, our histopathological results also showed that $\mathrm{NaF}$-induced the degeneration and necrosis of the tubular cells, inflammatory cell infiltration, swelled glomeruli as well as the renal tubular hyaline casts in a dose- and time-dependent manner from 21 to 42 days during the experiment.

\section{CONCLUSIONS}

The present study finds that $\mathrm{NaF}$ in excess of 12 $\mathrm{mg} / \mathrm{kg}$ can induce the renal histological lesions, and inflammatory responses by increasing the $\mathrm{NO}$ and $\mathrm{PGE}_{2}$ contents, iNOS activities and mRNA expression levels as
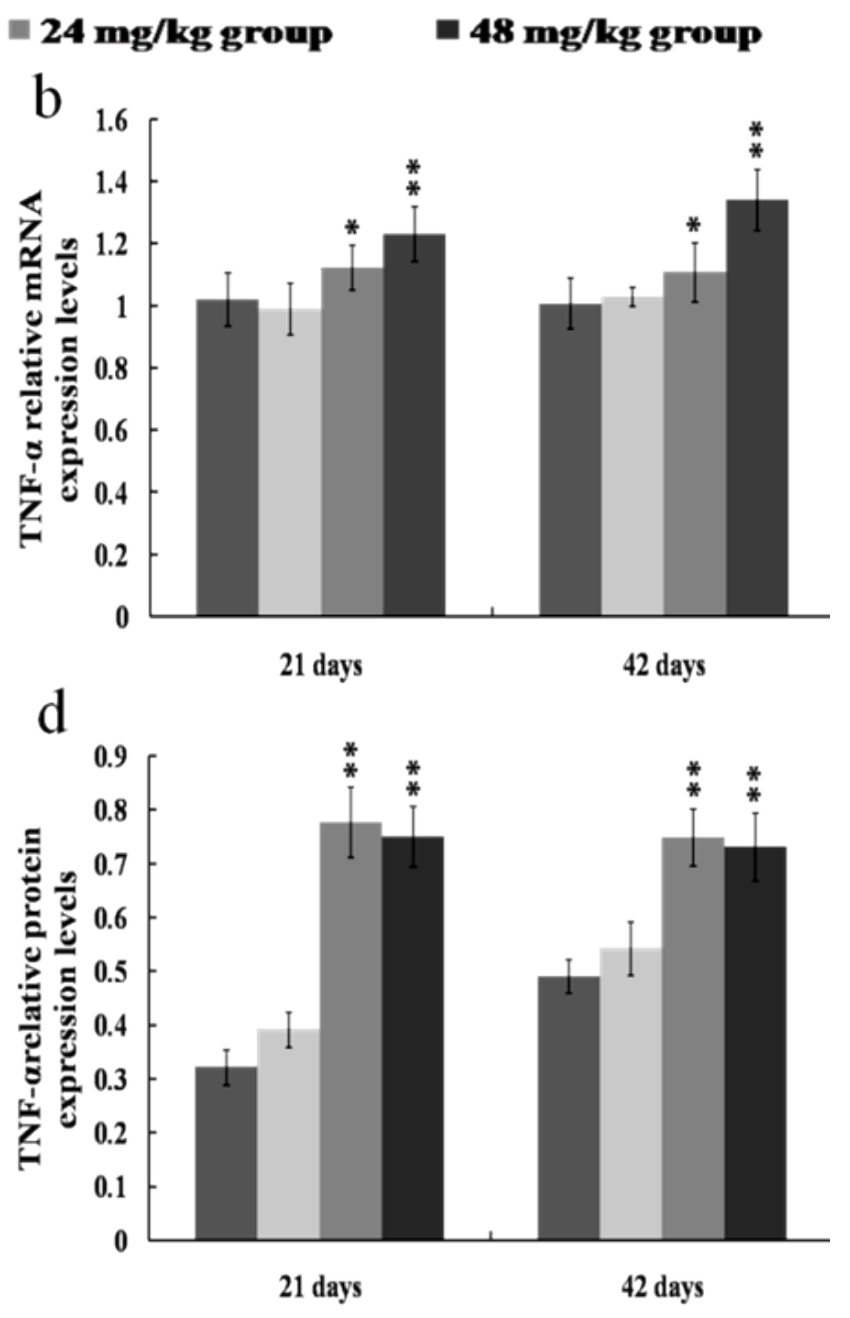

Figure 8: Changes of mRNA and protein expression levels of TNF- $\alpha$ in the kidney at 21 and 42 days of the experiment. a. The melting curve analysis of TNF- $\alpha$. b. The relative mRNA expression levels of TNF- $\alpha$. c. The western blot assay of TNF- $\alpha$. d. The relative protein expression levels of TNF- $\alpha$. CG: Control group; GI: $12 \mathrm{mg} / \mathrm{kg}$ group; GII: $24 \mathrm{mg} / \mathrm{kg}$ group; GIII: $48 \mathrm{mg} / \mathrm{kg}$ group. Data are presented with the mean \pm standard deviation $(n=8) .{ }^{*} p<0.05$, compared with the control group; $* * p<0.01$, compared with the control group. 
well as the COX-2, TNF- $\alpha$, IL-1 $\beta$, IL- 6 and IL- 8 mRNA and protein expression levels via the activation of $\mathrm{NF}-\kappa \mathrm{B}$ signaling pathway, and reducing the mRNA and protein expression levels of IL-4 and IL-10. The activation of NF$\kappa \mathrm{B}$ signaling pathway and reduction of anti-inflammatory mediator expression are the potential mechanisms of $\mathrm{NaF}$ induced renal inflammatory responses, as shown in Figure 14.

\section{MATERIALS AND METHODS}

\section{Chemicals and sources}

$\mathrm{NaF}$ was purchased from Chengdu Kelong Chemical Co., Ltd. (Chengdu, China). Reagent kits for determination of biochemical parameters were purchased from Nanjing Jiancheng Bioengineering Institute of China (Nanjing, China). RNAiso Plus, Prim-Script ${ }^{\mathrm{TM}}$ RT reagent Kit and
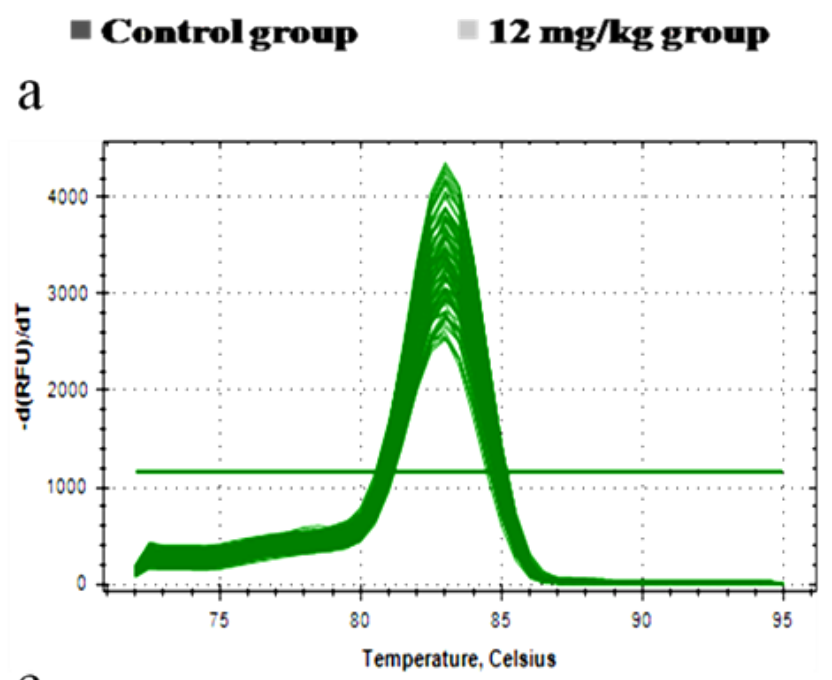

C

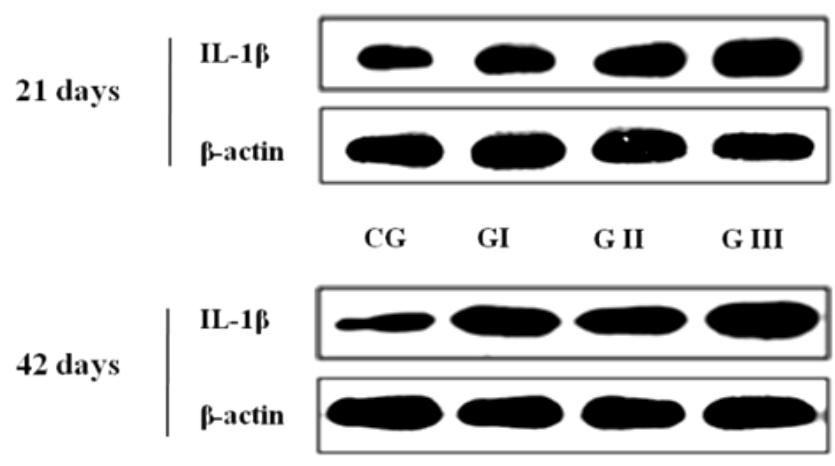

SYBR $^{\circledR}$ Premix Ex Taq ${ }^{\mathrm{TM}}$ II were obtained from Takara Biotechnology (Dalian) Co., Ltd. (Dalian, Liaoning, China). Radio-immunoprecipitation Assay (RIPA) lysis buffer (P0013C) and bicinchoninic acid (BCA) Protein Assay Kit (P0012) were purchased from Beyotime Biotechnology, China. RPMI 1640 (11875119) was

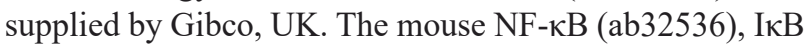
(ab32518) and COX-2 (ab179800) were obtained from Abcam, UK. IL-6 (12912), p-NF-кB (3033), and antirabbit IgG (7074P2) were purchased from Cell Signaling Technology, USA. TNF- $\alpha$ (sc-1351) and IL-10 (sc-1783) were supplied by Santa Cruz Biotechnology, Inc. (Santa Cruz, CA, USA). IL-1 $\beta$ (abs115412), IL-4 (abs116760) and bicinchoninic acid (BCA) were obtained from Absin Bioscience Inc. (Absin, Shanghai, China). Anti-goat IgG antibody (BL004A) was supplied by Biosharp Bioscience Inc. (Biosharp, Anhui, China). Other chemicals including $75 \%$ ethanol, 100\% ethanol, isopropyl alcohol and chloroform used in the experiment were of analytical grade.
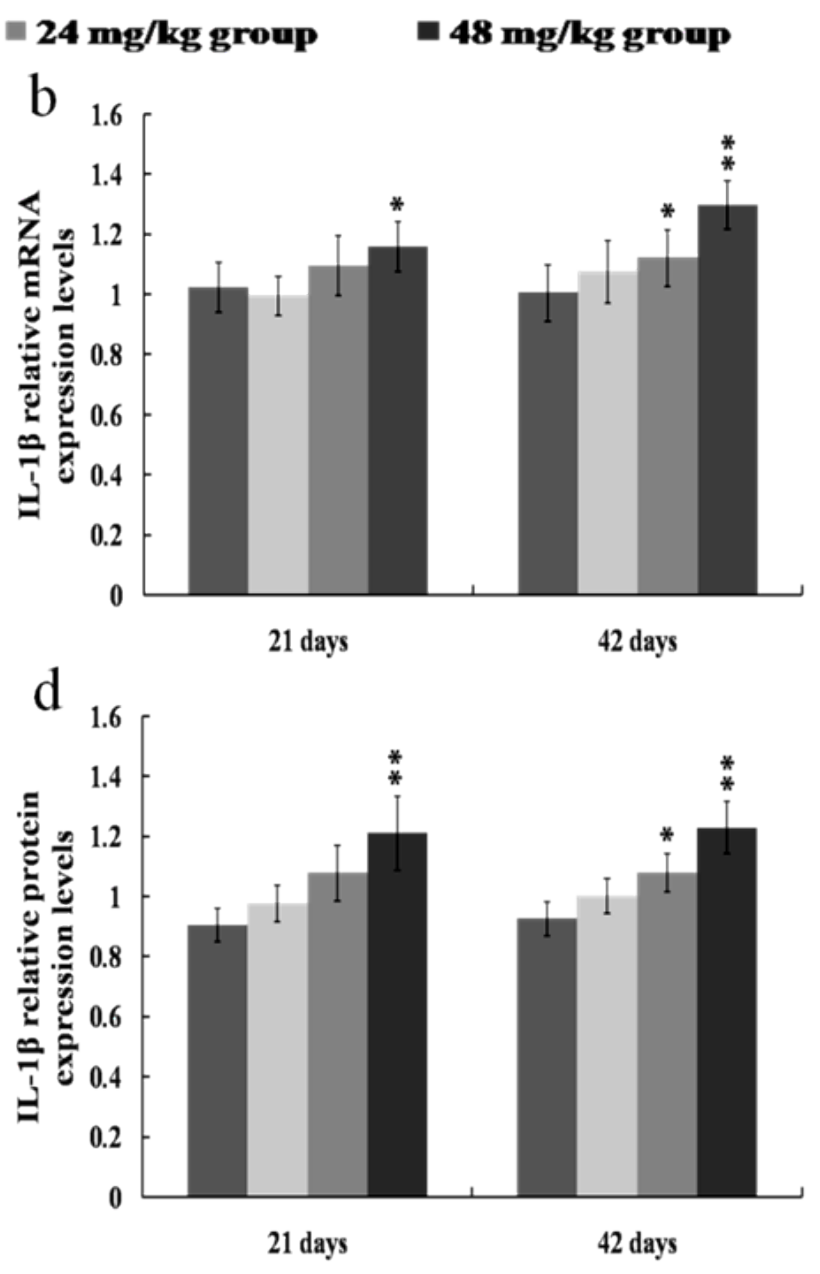

Figure 9: Changes of mRNA and protein expression levels of IL-1 $\beta$ in the kidney at 21 and 42 days of the experiment. a. The melting curve analysis of IL-1 $\beta$. b. The relative mRNA expression levels of IL-1 $\beta$. c. The western blot assay of IL-1 $\beta$. d. The relative protein expression levels of IL-1 $\beta$. CG: Control group; GI: $12 \mathrm{mg} / \mathrm{kg}$ group; GII: $24 \mathrm{mg} / \mathrm{kg}$ group; GIII: $48 \mathrm{mg} / \mathrm{kg}$ group. Data are presented with the mean \pm standard deviation $(n=8)$. ${ }^{*} p<0.05$, compared with the control group; $* * p<0.01$, compared with the control group. 


\section{Experimental animals and treatment}

A total of 240 four-week-old ICR mice obtained from the Chengdu Dossy Experimental Animals Co., Ltd. [License No. SCXK (Sichuan) 2008-24] were used in the present study. The animals were housed in separate polypropylene cages, and kept under the standard laboratory conditions (at a temperature of $20-22{ }^{\circ} \mathrm{C}$ with a $12 \mathrm{~h} \mathrm{light} / 12 \mathrm{~h}$ dark photoperiod and $55-60 \%$ humidity). Diet and water were provided ad libitum throughout the experimental period.

After one week of acclimation, animals were randomly divided into four equal groups with 60 mice in each. Control group was given orally distilled water only and served as untreated group. Groups I, II and III were given orally $\mathrm{NaF}$ at the dose of 12,24 and $48 \mathrm{mg} / \mathrm{kg}$ body weight, respectively. Mice were administered their respective doses daily by gavages for consecutively 42 days, and the gavage volume was $1 \mathrm{ml} / 100 \mathrm{~g}$ body weight.

All experimental procedures involving the use
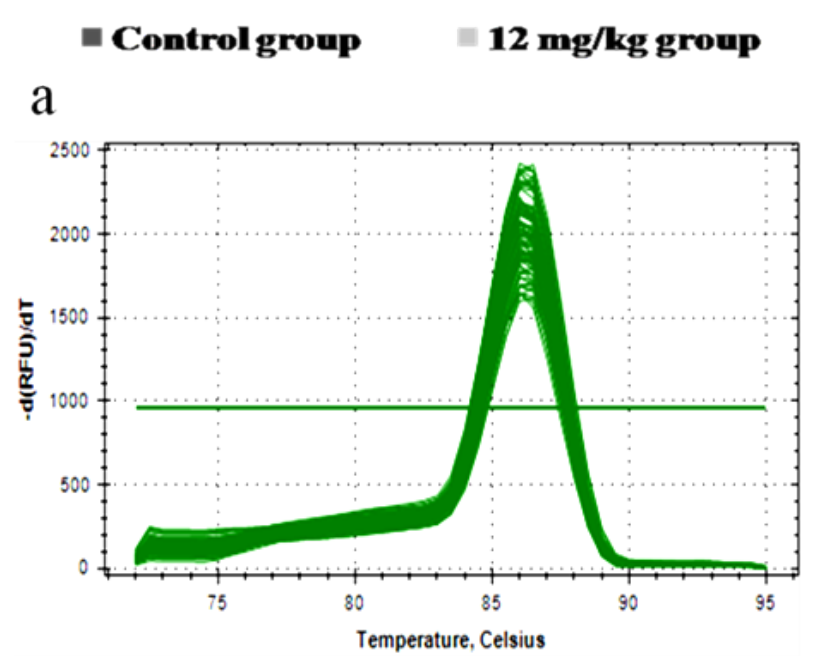

C

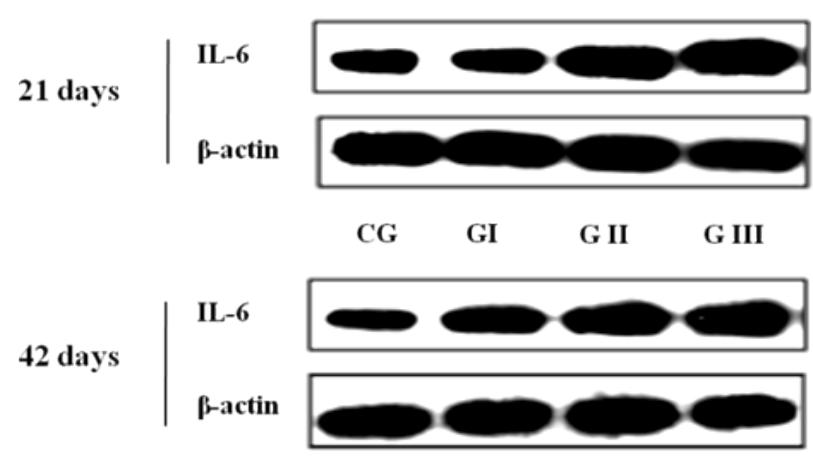

of mice were approved by the Animal Care and Use Committee, Sichuan Agricultural University.

\section{Histopathological observation}

At 21 and 42 days of the experiment, kidneys of eight mice in each group were removed, fixed in $4 \%$ paraformaldehyde, dehydrated with increasing concentrations of ethanol, cleared with xylene and embedded in paraffin. And then kidneys were serial sectioned at $5 \mu \mathrm{m}$ thickness, stained with hematoxylin and eosin (H\&E), and observed by light microscopy.

\section{Determination of NO contents and iNOS activities in the kidney}

At 21 and 42 days of the experiment, eight mice in each group were sacrificed and kidneys were removed immediately. Kidneys were washed using chilled saline solution, weighed, homogenized in nine volumes of ice-
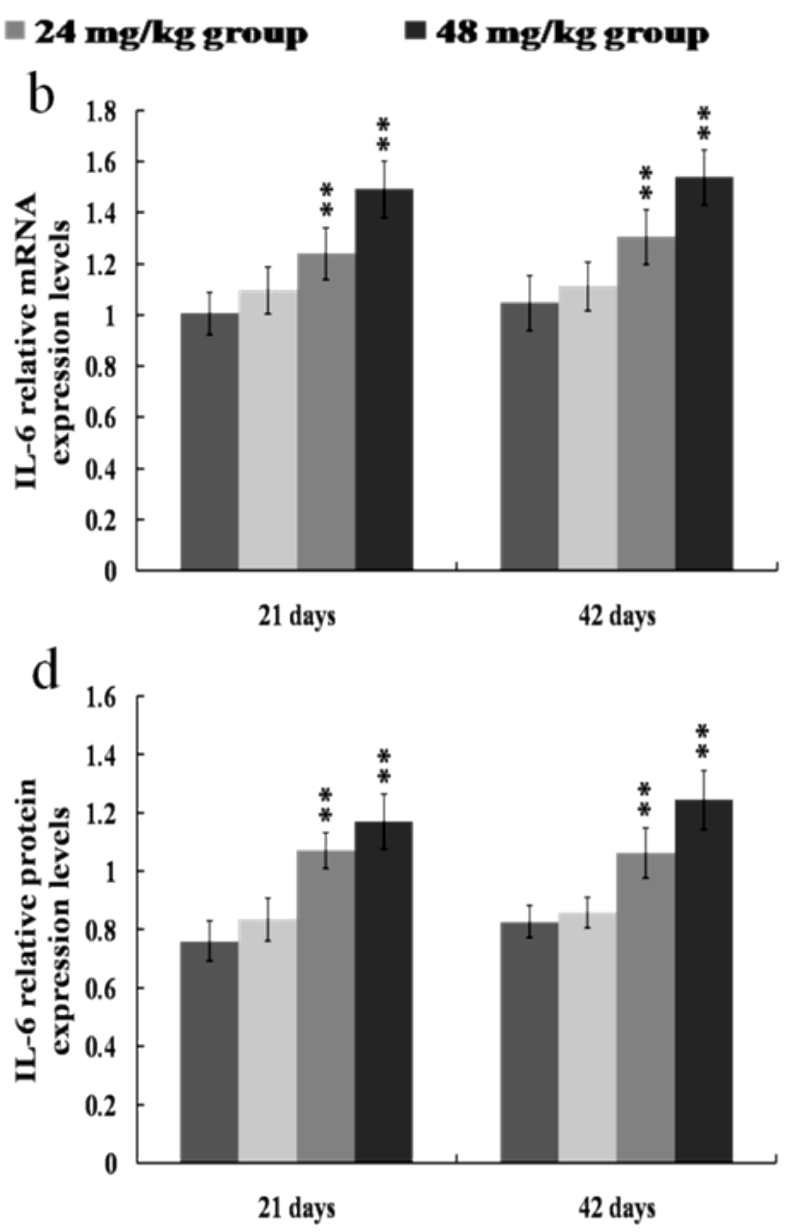

Figure 10: Changes of mRNA and protein expression levels of IL-6 in the kidney at 21 and 42 days of the experiment. a. The melting curve analysis of IL-6. b. The relative mRNA expression levels of IL-6. c. The western blot assay of IL-6. d. The relative protein expression levels of IL-6. CG: Control group; GI: $12 \mathrm{mg} / \mathrm{kg}$ group; GII: $24 \mathrm{mg} / \mathrm{kg}$ group; GIII: $48 \mathrm{mg} / \mathrm{kg}$ group. Data are presented with the mean \pm standard deviation $(n=8) .{ }^{*} p<0.05$, compared with the control group; ${ }^{* *} p<0.01$, compared with the control group. 
cold $0.9 \% \mathrm{NaCl}$ solution and centrifuged at $3500 \mathrm{rpm}$ for $10 \mathrm{~min}$ at $4^{\circ} \mathrm{C}$. Then the supernatant was collected for the determination of NO contents and iNOS activities by biochemical methods according to the instructions of the reagent kits (NO, A013-2; iNOS, A014-1; Nanjing Jiancheng, China).

\section{Determination of $\mathrm{PGE}_{2}$ contents in the kidney by ELISA}

At 21 and 42 days of the experiment, kidneys of eight mice in each group were taken to measure the $\mathrm{PGE}_{2}$ contents. Kidneys were weighed and homogenized in nine volumes of ice-cold $0.9 \% \mathrm{NaCl}$ solution in a chilled homogenizer, and immediately centrifuged at $3500 \mathrm{rpm}$ for $10 \mathrm{~min}$ at $4^{\circ} \mathrm{C}$. Then the supernatant was immediately assayed for the $\mathrm{PGE}_{2}$ contents by ELISA as described by Gaca et al. [54]. The detected $\mathrm{PGE}_{2}$ contents were

a Control group $\quad 12 \mathrm{mg} / \mathrm{kg}$ group

a

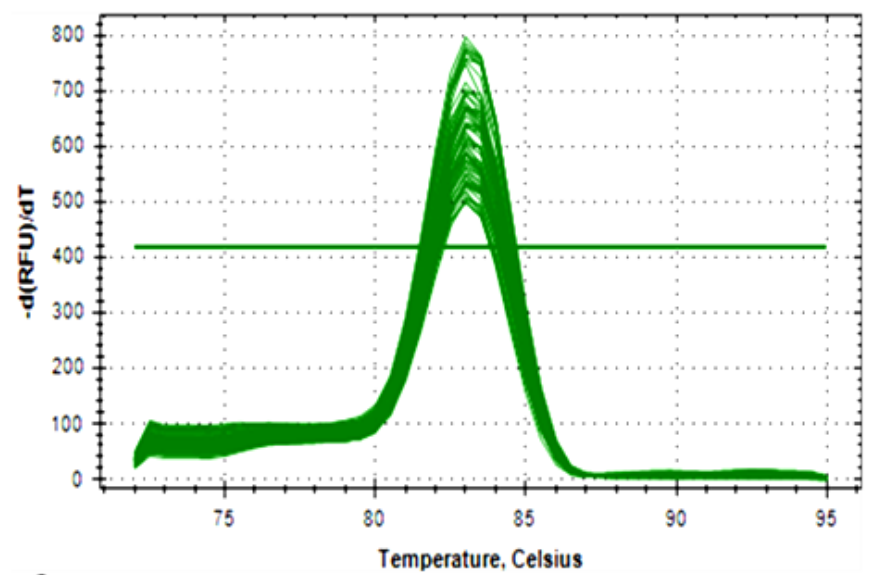

C

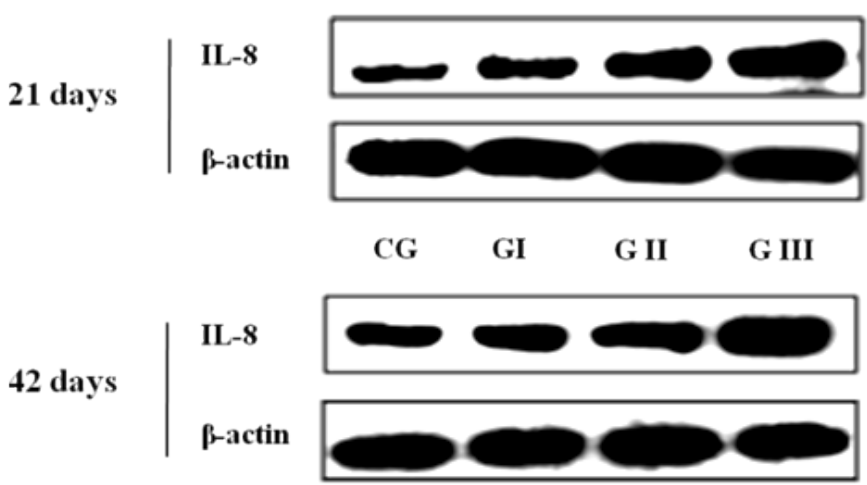

determined by the standard curve and were expressed as microgram per milliliter $(\mathrm{pg} / \mathrm{ml})$.

\section{Determination of inflammatory mediator mRNA expression levels in the kidney by qRT-PCR}

At 21 and 42 days of the experiment, kidneys of eight mice in each group were removed, stored in liquid nitrogen, and then homogenized with liquid nitrogen for RNA extraction. The methods of RNA extraction and qRTPCR analysis were same as the described by Guo et al. [55]. Briefly, the total RNA of the kidneys were extracted using RNAiso Plus (9109; Takara, China) following the manufacturer's instructions. The cDNA, used as the template for qRT-PCR analysis, was synthesized using a Prim-Script ${ }^{\mathrm{TM}}$ RT reagent Kit (RR047A, Takara, China) following the manufacturer's instructions. Specific primers for the genes were designed and synthesized by
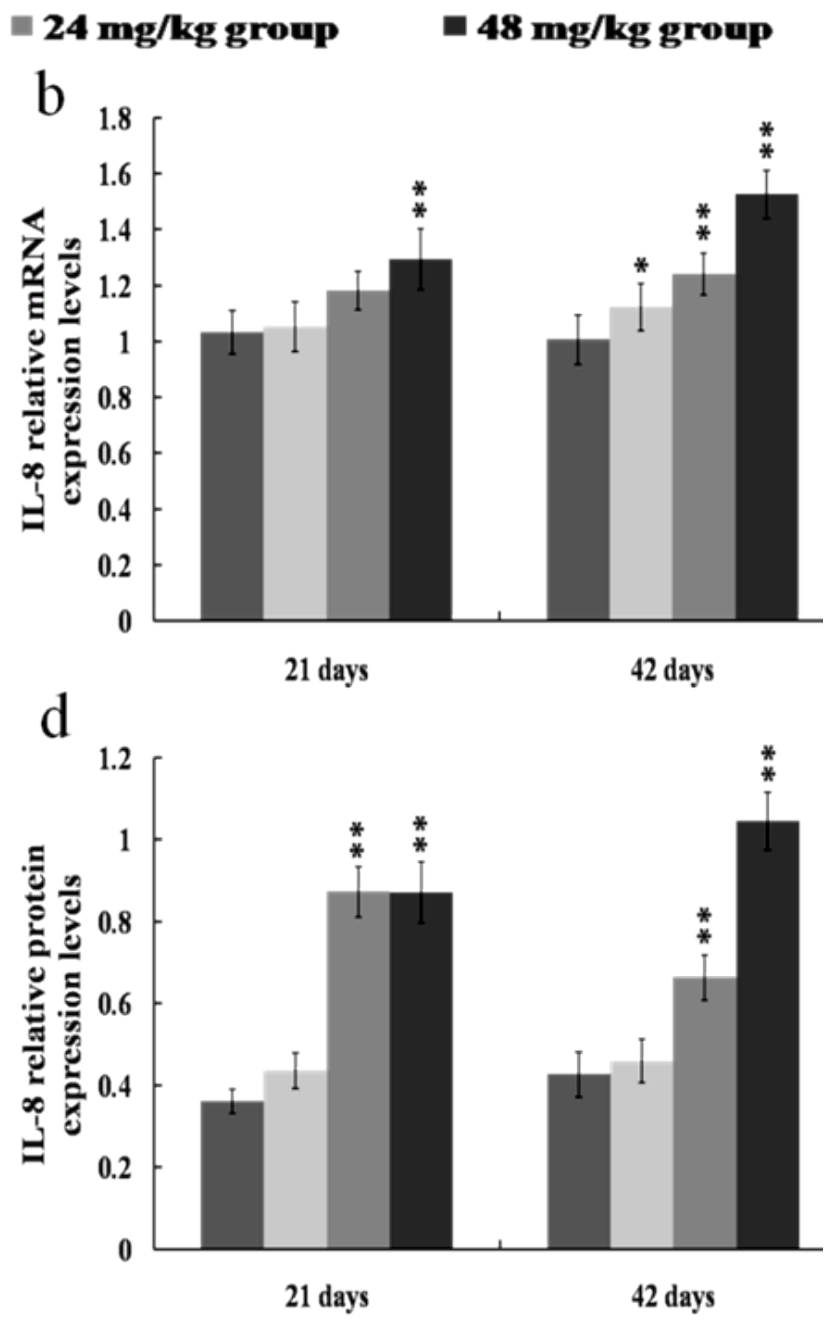

Figure 11: Changes of mRNA and protein expression levels of IL-8 in the kidney at 21 and 42 days of the experiment. a. The melting curve analysis of IL-8. b. The relative mRNA expression levels of IL-8. c. The western blot assay of IL-8. d. The relative protein expression levels of IL-8. CG: Control group; GI: $12 \mathrm{mg} / \mathrm{kg}$ group; GII: $24 \mathrm{mg} / \mathrm{kg}$ group; GIII: $48 \mathrm{mg} / \mathrm{kg}$ group. Data are presented with the mean \pm standard deviation $(n=8)$. $* p<0.05$, compared with the control group; $* * p<0.01$, compared with the control group. 
Table 1: Primer sequences of genes selected for analysis by qRT-PCR

\begin{tabular}{|c|c|c|c|c|c|}
\hline $\begin{array}{l}\text { Target } \\
\text { gene }\end{array}$ & Accession number & Primer & Primer sequence $\left(5^{\prime}-3^{\prime}\right)$ & Product size & $\operatorname{Tm}\left({ }^{\circ} \mathbf{C}\right)$ \\
\hline \multirow[t]{2}{*}{$\mathrm{NF}-\kappa \mathrm{B}$} & NM_008689 & Forward & GTAACAGCAGGACCCAAGGA & $121 \mathrm{bp}$ & 59 \\
\hline & & Reverse & AGCCCCTAATACACGCCTCT & & \\
\hline \multirow[t]{2}{*}{ I $\mathrm{B}$} & NM_010908 & Forward & TGAGGACGAGGACGATAAGC & $159 \mathrm{bp}$ & 60 \\
\hline & & Reverse & TCAGGAAGAGGTTTGGATGC & & \\
\hline \multirow[t]{2}{*}{ iNOS } & NM_010927 & Forward & GAATCTTGGAGCGAGTTGTGG & $139 \mathrm{bp}$ & 60 \\
\hline & & Reverse & AGGAAGTAGGTGAGGGCTTGG & & \\
\hline \multirow[t]{2}{*}{$\mathrm{COX}-2$} & NM_011198 & Forward & GCCTGGTCTGATGATGTATGC & $124 \mathrm{bp}$ & 61 \\
\hline & & Reverse & GAGTATGAGTCTGCTGGTTTGG & & \\
\hline \multirow[t]{2}{*}{ TNF- $\alpha$} & NM_013693 & Forward & CACGTCGTAGCAAACCACC & $88 \mathrm{bp}$ & 59 \\
\hline & & Reverse & TGAGATCCATGCCGTTGGC & & \\
\hline \multirow[t]{2}{*}{ IL-1 $\beta$} & NM_008361 & Forward & AATGCCACCTTTTGACAGTGAT & $132 \mathrm{bp}$ & 61 \\
\hline & & Reverse & TGCTGCGAGATTTGAAGCTG & & \\
\hline \multirow[t]{2}{*}{ IL-6 } & NM_031168 & Forward & AGGATACCACTCCCAACAGACC & $141 \mathrm{bp}$ & 60 \\
\hline & & Reverse & AAGTGCATCATCGTTGTTCATACA & & \\
\hline \multirow[t]{2}{*}{ IL-8 } & NM_011339 & Forward & TTTCCACCGGCAATGAAG & $115 \mathrm{bp}$ & 59 \\
\hline & & Reverse & TAGAGGTCTCCCGAATTGGA & & \\
\hline \multirow[t]{2}{*}{ IL-4 } & NM_021283 & Forward & GTCATCCTGCTCTTCTTTCTCG & $115 \mathrm{bp}$ & 61 \\
\hline & & Reverse & ATGGCGTCCCTTCTCCTGT & & \\
\hline \multirow[t]{2}{*}{ IL-10 } & NM_010548 & Forward & GACAACATACTGCTAACCGACT & $252 \mathrm{bp}$ & 59 \\
\hline & & Reverse & ATCACTCTTCACCTGCTCCAC & & \\
\hline \multirow[t]{2}{*}{$\beta$-actin } & NM_007393 & Forward & GCTGTGCTATGTTGCTCTAG & $117 \mathrm{bp}$ & 59 \\
\hline & & Reverse & CGCTCGTTGCCAATAGTG & & \\
\hline
\end{tabular}
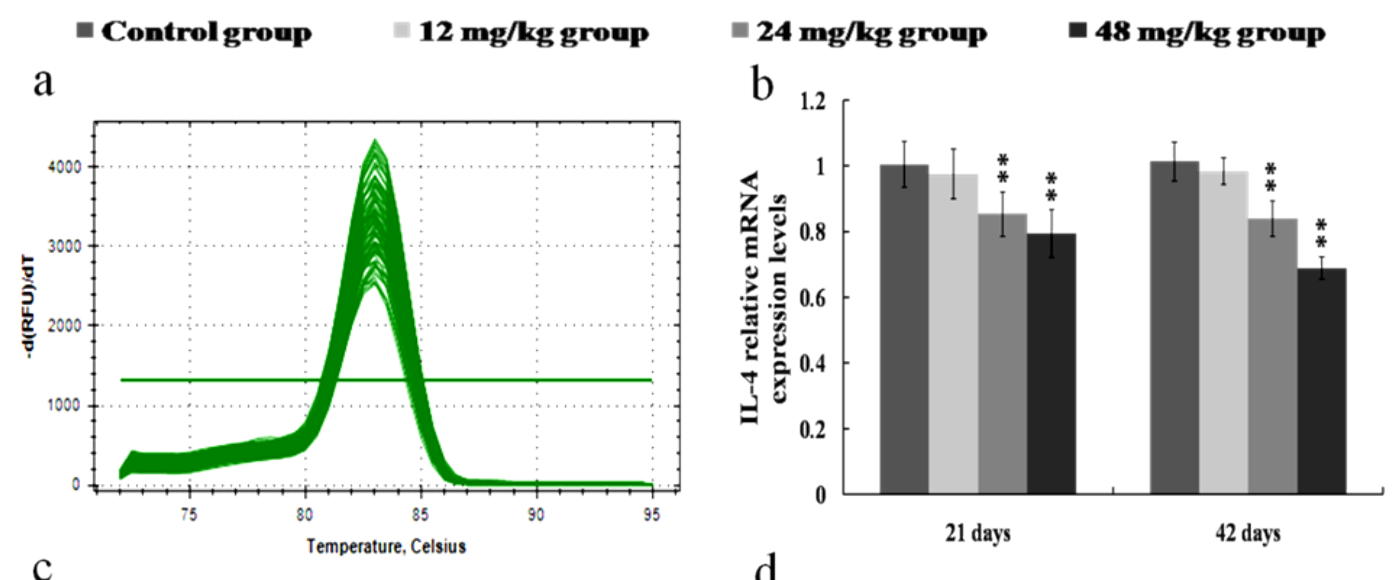

$\mathrm{C}$

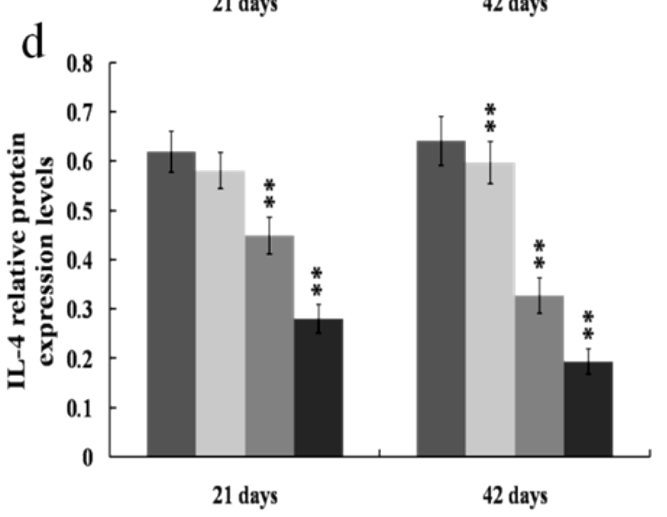

Figure 12: Changes of mRNA and protein expression levels of IL-4 in the kidney at 21 and 42 days of the experiment. a. The melting curve analysis of IL-4. b. The relative mRNA expression levels of IL-4. c. The western blot assay of IL-4. d. The relative protein expression levels of IL-4. CG: Control group; GI: $12 \mathrm{mg} / \mathrm{kg}$ group; GII: $24 \mathrm{mg} / \mathrm{kg}$ group; GIII: $48 \mathrm{mg} / \mathrm{kg}$ group. Data are presented with the mean \pm standard deviation $(n=8) .{ }^{*} p<0.05$, compared with the control group; $* * p<0.01$, compared with the control group. 

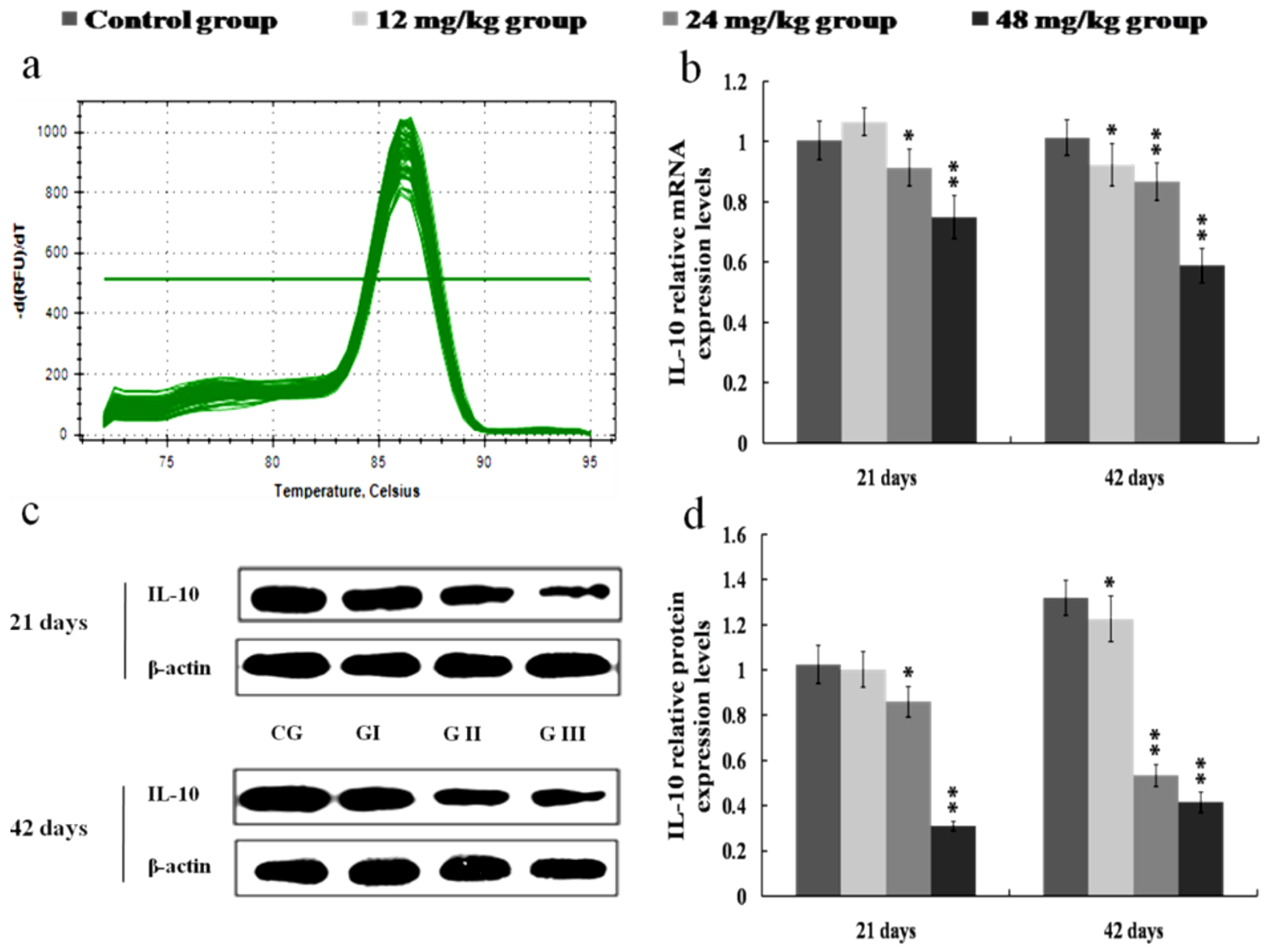

Figure 13: Changes of mRNA and protein expression levels of IL-10 in the kidney at 21 and 42 days of the experiment. a. The melting curve analysis of IL-10. b. The relative mRNA expression levels of IL-10. $\mathbf{c}$. The western blot assay of IL-10. d. The relative protein expression levels of IL-10. CG: Control group; GI: $12 \mathrm{mg} / \mathrm{kg}$ group; GII: $24 \mathrm{mg} / \mathrm{kg}$ group; GIII: $48 \mathrm{mg} / \mathrm{kg}$ group. Data are presented with the mean \pm standard deviation $(n=8) .{ }^{*} p<0.05$, compared with the control group; ${ }^{* *} p<0.01$, compared with the control group.

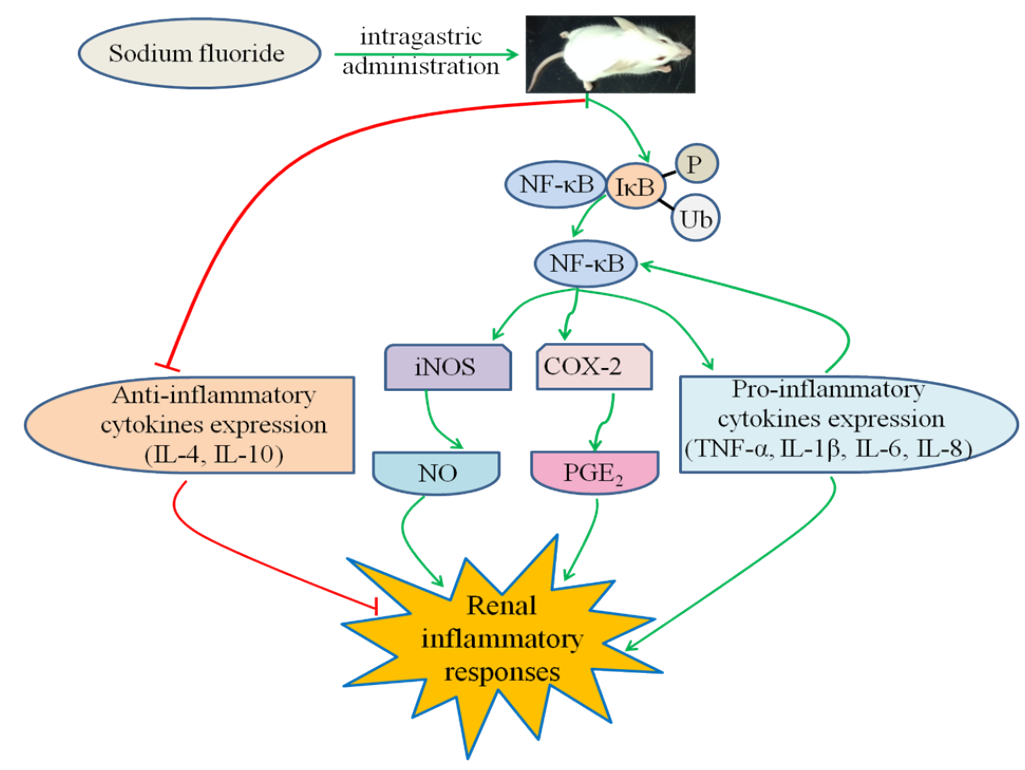

Figure 14: Schematic of NaF-induced the renal inflammatory responses in mice. $\mathrm{NaF}$ can induce the renal inflammatory responses by increasing the NO and PGE 2 contents, iNOS activities and mRNA expression levels as well as the COX-2, TNF- $\alpha$, IL- $1 \beta$, IL-6 and IL-8 mRNA and protein expression levels via the activation of NF- $\mathrm{kB}$ signaling pathway, and reducing the mRNA and protein expression levels of IL-4 and IL-10. The activation of NF- $\mathrm{KB}$ signaling pathway and reduction of anti-inflammatory mediator expression are the potential mechanisms of NaF-induced renal inflammatory responses. 
Sangon (Shanghai, China) according to the Mus musculus sequences, and the expression levels of NF- $\mathrm{BB}, \mathrm{I} \kappa \mathrm{B}$, iNOS, COX-2, TNF- $\alpha$, IL- $1 \beta$, IL-6, IL- 8 , IL-4 and IL10 were normalized to the expression levels of a house keeping gene, $\beta$-actin (Table 1 ).

qRT-PCR was performed on a Thermal Cycler (C1000, BIO RAD, USA) using SYBR ${ }^{\circledR}$ Premix Ex Taq ${ }^{\mathrm{TM}}$ II (RR820A, Takara, China) according to the standard protocols. Gene expression values of the control group at 21 and 42 days of the experiment were used for gene expression calibration. The results of qRT-PCR were analyzed by $2^{-\Delta \Delta \mathrm{CT}}$ method [56].

\section{Determination of inflammatory mediator protein expression levels in the kidney by Western blot}

The same samples used for measuring the mRNA expression levels of inflammatory mediator were also used for measuring their corresponding protein expression levels. Kidneys were homogenized in liquid nitrogen with RIPA lysis buffer supplemented with $1 \mathrm{mM}$ phenylmethylsulfonyl fluoride (PMSF). The protein contents of kidney were measured by using the BCA Protein Assay kit. Then the protein samples were separated by sodium dodecyl sulfate-polyacrylamide gel electrophoresis (SDS-PAGE) (10\%-15\% gels), and protein standards were used as molecular weight marker. After electrophoresis, proteins were transferred to nitrocellulose filter membranes. The membranes were blocked with $5 \%$ nonfat-dried milk in phosphate-buffered saline with $0.1 \%$ Tween 20 (PBST) for $1 \mathrm{~h}$ and then incubated with the primary antibodies overnight at $4^{\circ} \mathrm{C}$. The primary antibodies were NF- $\kappa \mathrm{B}$ (dilution, 1:5000), I $\kappa \mathrm{B}$ (dilution, 1:1000), COX-2 (dilution, 1:1000), TNF- $\alpha$ (dilution, $1: 100)$, IL-1 $\beta$ (dilution, 1:1000), IL-6 (dilution, 1:1000), IL-8 (dilution, 1:800), IL-4 (dilution, 1:500) and IL-10 (dilution, 1:100). After primary antibodies were incubated overnight, the membranes were washed three times with PBST for $10 \mathrm{~min}$ and incubated with the biotin-conjugated secondary antibodies for $1 \mathrm{~h}$ with gentle shaking, and washed again with PBST. Blots were visualized by ECL ${ }^{\mathrm{TM}}$ (Bio-Rad, Hercules, CA, USA) and X-ray film.

\section{Statistical analysis}

The SPSS 17.0 statistical software package programme for windows was used for statistical tests. All results were expressed as mean \pm standard deviation. Differences between group means were estimated using one way analysis of variance (ANOVA). A value of $p<$ 0.05 or $p<0.01$ was accepted as statistically significant differences.

\section{ACKNOWLEDGMENTS}

This research was supported by the program for Changjiang scholars and the university innovative research team (IRT 0848), and the Shuangzhi project of Sichuan Agricultural University (03570327; 03571198).

\section{CONFLICTS OF INTEREST}

The authors declare that there are no conflicts of interest.

\section{REFERENCES}

1. Barbier O, Arreola-Mendoza L, Del Razo LM. Molecular mechanisms of fluoride toxicity. Chem-Biol Interact. 2010; 188:319-333.

2. Meenakshi, Maheshwari RC. Fluoride in drinking water and its removal. J Hazard Mater. 2006; 137: 456-463.

3. Zheng X, Sun Y, Ke L, Ouyang W, Zhang Z. Molecular mechanism of brain impairment caused by drinkingacquired fluorosis and selenium intervention. Environ Toxicol Phar. 2016; 43:134-139.

4. Zhang KL, Lou DD, Guan ZZ. Activation of the AGE/ RAGE system in the brains of rats and in SH-SY5Y cells exposed to high level of fluoride might connect to oxidative stress. Neurotoxicol Teratol. 2015; 48:49-55.

5. Jian JC, Wen JX, Jin LC, Jie S, Ru HJ, Mei YL. Fluoride caused thyroid endocrine disruption inmale zebrafish (Danio rerio). Aquat Toxicol. 2015; 171:48-58.

6. Liu HL, Hou CC, Zeng Q, Zhao L, Cui YS, Yu LY, Wang LZ, Zhao Y, Nie JY, Zhang B, Wang AG. Role of endoplasmic reticulum stress-induced apoptosis in rat thyroid toxicity caused by excess fluoride and/or iodide. Environ Toxicol Phar. 2016; 46:277-285.

7. Chattopadhyay A, Podder S, Agarwal S, Bhattacharya S. Fluoride-induced histopathology and synthesis of stress protein in liver and kidney of mice. Arch Toxicol. 2011; 85:327-335.

8. Zhao L, Yu Y, Deng C. Protein and mRNA expression of Shh, Smo and Glil and inhibition by cyclopamine in hepatocytes of rats with chronic fluorosis. Toxicol Lett. 2014; 225:318-324.

9. Gong T, Bai CM, Chen T, Peng X, Cui HM. Effect of high fluorine on the antioxidant function and ultrastructure of liver in chickens. Chinese J Anim Vet Sci. 2009; 40:13891394.

10. Cao JL, Chen JJ, Wang JD, Jia RH, Xue WJ, Luo YJ, Gan $\mathrm{X}$. Effects of fluoride on liver apoptosis and Bcl-2, Bax protein expression in freshwater teleost, Cyprinus carpio. Chemosphere. 2013; 91:1203-1212.

11. Deng HD, Kuang P, Cui HM, Chen L, Fang J, Zuo ZC, Deng JL, Wang X, Zhao L. Sodium fluoride induces apoptosis in cultured splenic lymphocytes from mice. 
Oncotarget. 2016; 7:67880-67900. doi: 10.18632/ oncotarget.12081.

12. Deng HD, Kuang P, Cui HM, Chen L, Luo Q, Fang J, Zuo ZC, Deng JL, Wang X, Zhao L. Sodium fluoride (NaF) induces the splenic apoptosis via endoplasmic reticulum (ER) stress pathway in vivo and in vitro. Aging (Albany NY). 2016; 8:3552-3567. doi: 10.18632/aging.101150.

13. Kuang P, Deng HD, Cui HM, Chen L, Fang J, Zuo ZC, Deng JL, Wang X, Zhao L. Sodium fluoride (NaF) causes toxic effects on splenic development in mice. Oncotarget. 2017; 8:4703-4717. doi: 10.18632/oncotarget.13971.

14. Kuang P, Deng HD, Cui HM, Chen L, Guo HR, Fang J, Zuo ZC, Deng JL, Wang X, Zhao L. Suppressive effects of sodium fluoride on cultured splenic lymphocyte proliferation in mice. Oncotarget. 2016; 7:61905-61915. doi: 10.18632/oncotarget.11308.

15. Varol E, Akcay S, Erosoy IH, Koroglu BK, Varol S. Impact of chronic fluorosis on left ventricular diastolic and global functions. Sci Total Environ. 2010; 408:2295-2298.

16. Ma YQ, Niu RY, Sun ZL, Wang JM, Luo GY, Zhang JH, Wang JD. Inflammatory responses induced by fluoride and arsenic at toxic concentration in rabbit aorta. Arch Toxicol. 2012; 86:849-856.

17. Luo Q, Cui HM, Peng X, Fang J, Zuo ZC, Deng JL, Liu J, Deng YB. Suppressive effects of dietary high fluorine on the intestinal development in broilers. Biol Trace Elem Res. 2013; 156:153-165.

18. Luo Q, Cui HM, Peng X, Fang J, Zuo ZC, Liu J, Wu BY, Deng YB. The association between cytokines and intestinal mucosal immunity among broilers fed on diets supplemented with fluorine. Biol Trace Elem Res. 2013; 152:212-218.

19. Chauhan SS, Ojha S, Mahmood A. Modulation of lipid peroxidation and antioxidant defense systems in rat intestine by subchronic fluoride and ethanol administration. Alcohol. 2011; 45:663-672.

20. Zhang S, Jiang C, Liu H, Guan Z, Zeng Q, Zhang C, Lei R, Xia T, Gao H, Yang L, Chen Y, Wu X, Zhang X, et al. Fluoride-elicited developmental testicular toxicity in rats: Roles of endoplasmic reticulum stress and inflammatory response. Toxicol appl pharm. 2013; 271:206-215.

21. Wei R, Luo G, Sun Z, Wang S, Wang J. Chronic fluoride exposure-induced testicular toxicity is associated with inflammatory response in mice. Chemosphere. 2016; 153:419-425.

22. Chen T, Cui H, Cui Y, Bai C, Gong T, Peng X. Cell-cycle blockage associated with increased apoptotic cells in the thymus of chickens fed on diets high in fluorine. Hum Exp Toxicol. 2011; 30:685-692.

23. Stawiarska-Pięta B, Grzegorzak N, Kuczera K, Helis A, Zalejska-Fiolka J, Bielec B, Birkner E, Kubina R. The effect of antioxidants on the morphological picture of thymus and heart of rats intoxicated with sodium fluoride. Toxicol Lett. 2013; 221:S77.
24. Liu J, Cui HM, Peng X, Fang J, Zuo ZC, Deng JL, Wang HS, Wu BY, Deng YX, Wang KP. Decreased IgA+ B cells population and $\operatorname{IgA}$, IgG, IgM contents of the cecal tonsil induced by dietary high fluorine in broilers. Inter J Env Res Pub Heal. 2013; 10:1775-1785.

25. Liu J, Cui HM, Peng X, Fang J, Zuo ZC, Wang HS, Wu BY, Deng YX, Wang KP. Dietary high fluorine induces apoptosis and alters Bcl-2, Bax, and Caspase-3 protein expression in the cecal tonsil lymphocytes of broilers. Biol Trace Elem Res. 2013; 152:25-30.

26. Chen T, Cui HM, Cui Y, Bai CM, Gong T. Effect of dietary high fluorine on the morphologic structure, cell cycle and apoptosis of bursa of fabricius in broilers. Chinese J Anim Vet Sci. 2009; 40:1235-1243.

27. Cao J, Chen J, Xie L, Wang J, Feng C, Song J. Protective properties of sesamin against fluoride-induced oxidative stress and apoptosis in kidney of carp (Cyprinus carpio) via JNK signaling pathway. Aquat Toxicol. 2015; 167:180-190.

28. Wasana HM, Perera GD, De Gunawardena PS, Bandara J. The impact of aluminum, fluoride, and aluminum-fluoride complexes in drinking water on chronic kidney disease. Environ Sci Pollut R. 2015; 22:11001-11009.

29. Martins JD, Liberal J, Silva A, Ferreira I, Neves BM, Cruz MT. Autophagy and inflammasome interplay. Dna Cell Biol. 2015; 34:274-281.

30. Wu Y, Jin F, Li F, Wang L, Wang Q, Ren Z, Wang Y. In vitro and in vivo anti-inflammatory effects of the aflavin3,3'-digallate on lipopolysaccharide-induced inflammation. Eur J Pharmacol. 2016; 794:52-60.

31. Beyer I, Mets T, Bautmans I. Chronic low-grade inflammation and age-related sarcopenia. Curr Opin Clin Nutr. 2012; 15:12-22.

32. Gutowska I, Baranowska-Bosiacka I, Goschorska M, Kolasa A, Lukomska A, Jakubczyk K, Dec K, Chlubek D. Fluoride as a factor initiating and potentiating inflammation in THP1 differentiated monocytes/macrophages. Toxicol in Vitro. 2015; 29:1661-1668.

33. Ridley W, Matsuoka M. Fluoride-induced cyclooxygenase-2 expression and prostaglandin E2 production in A549 human pulmonary epithelial cells. Toxicol Lett. 2009; 188:180185.

34. Villa A, Anabalon M, Zohouri V, Maguire A, Franco AM, Rugg-Gunn A. Relationships between fluoride intake, urinary fluoride excretion and fluoride retention in children and adults: an analysis of available data. Afr J Biotechnol. 2010; 9:531-535.

35. Gukovsky I, Gukovskaya A. Nuclear factor- $\kappa$ B in pancreatitis: Jack-of-all-trades, but which one is more important? Gastroenterology. 2013; 144:26-29.

36. Tian Y, Huo M, Li G, Wang J. Regulation of LPSinduced mRNA expression of pro-inflammatory cytokines via alteration of NF- $\mathrm{B}$ activity in mouse peritoneal macrophages exposed to fluoride. Chemosphere. 2016; 161:89-95. 
37. Yan N, Liu Y, Liu SN, Cao SQ, Wang F, Wang ZD, Xi $\mathrm{SH}$. Fluoride-induced Nneuron apoptosis and expressions of inflammatory factors by activating microglia in rat brain. Mol Neurobiol. 2016; 53:4449-4460.

38. De la Fuente B, Vázquez M, Rocha RA, Devesa V, Vélez D. Effects of sodium fluoride on immune response in murine macrophages. Toxicol in Vitro. 2016; 34:81-87.

39. Refsnes M, Skuland T, Lag M, Schwarze PE, Ovrevik J. Differential NF- $\mathrm{B}$ and MAPK activation underlies fluoride- and TPA-mediated CXCL8 (IL-8) induction in lung epithelial cells. Inflamm Res. 2014; 7:169-185.

40. Wang HW, Zhou BH, Cao JW, Zhao J, Zhao WP, Tan PP. Pro-inflammatory cytokines are involved in fluorideinduced cytotoxic potential in HeLa cells. Biol Trace Elem Res. 2017; 175:98-102.

41. Sanz AB, Sanchez-Nino MD, Ramos AM, Moreno JA, Santamaria B, Ruiz-Ortega M, Egido J, Ortiz A. NF-кB in renal inflammation. J Am Soc Nephrol. 2010; 21:12541262.

42. Nakayama H, Ikebe T, Beppu M, Shirasuna K. High expression levels of nuclear factor $\kappa \mathrm{B}$, I $\kappa \mathrm{B}$ kinase $\alpha$ and Akt kinase in squamous cell carcinoma of the oral cavity. Cancer. 2001; 92:3037-3044.

43. Tak PP, Firestein GS. NF-kappaB: a key role in inflammatory diseases. J Clin Invest. 2001; 107:7-11.

44. Luo T, Qin J, Liu M, Luo J, Ding F, Wang ML, Zheng LM. Astragalus polysaccharide attenuates lipopolysaccharideinduced inflammatory responses in microglial cells: regulation of protein kinase $\mathrm{B}$ and nuclear factor $-\mathrm{\kappa} B$ signaling. Inflamm Res. 2015; 64:205-212.

45. Delker SL, Xue F, Jamal J, Silverman RB, Poulos TL. Role of zinc in isoform-selective inhibitor binding to neuronal nitric oxide synthase. Biochemistry. 2010; 49:10803-10810.

46. Nader M, Vicente G, Salvan da Rosa J, Lima TC, Barbosa AM, Santos AD, Barison A, Dalmarco EM, Biavatti MW, Frode TS. Jungia sellowii suppresses the carrageenaninduced inflammatory response in the mouse model of pleurisy. Inflammopharmacology. 2014; 22:351-365.

47. Lee KM, Kang BS, Lee HL, Son SJ, Hwang SH, Kim DS, Park JS, Cho HJ. Spinal NF-kB activation induces COX-2 upregulation and contributes to inflammatory pain hypersensitivity. Eur J Neurosci. 2004; 19: 3375-3381.
48. Pandey GN, Rizavi HS, Ren X, Fareed J, Hoppensteadt DA, Roberts RC, Conley RR, Dwivedi Y. Proinflammatory cytokines in the prefrontal cortex of teenage suicide victims. J Psychiatr Res. 2012; 46:57-63.

49. Cardinaux JR, Allaman I, Magistretti PJ. Pro-inflammatory cytokines induce the transcription factors $\mathrm{C} / \mathrm{EBP} \beta$ and $\mathrm{C} /$ EBP $\delta$ in astrocytes. Glia. 2015; 29:91-97.

50. Van Strien ME, Mercier D, Drukarch B, Brevé JJ, Poole S, Binnekade R, Bol JG, Blits B, Verhaagen J, Van Dam AM. Anti-inflammatory effect by lentiviral-mediated overexpression of IL-10 or IL-1 receptor antagonist in rat glial cells and macrophages. Gene Ther. 2010; 17:662-671.

51. Morita Y, Yamamura M, Kawashima M, Aita T, Harada S, Okamoto H, Inoue H, Makino H. Differential in vitro effects of IL-4, IL-10, and IL-13 on proinflammatory cytokine production and fibroblast proliferation in rheumatoid synovium. Rheumatol Int. 2001; 20:49-54.

52. Deng YB, Cui HM, Peng X, Fang J, Zuo ZC, Deng JL, Luo Q. High dietary fluorine alteration of serum cytokine and immunoglobulin in broilers. Fluoride. 2013; 46:118-127.

53. Liu J, Cui HM, Peng X, Fang J, Zuo ZC, Wang HS, Wu BY, Deng YX, Wang KP. Changes induced by high dietary fluorine in the cecal tonsil cytokine content of broilers. Fluoride. 2012; 45:101-106.

54. Gaça MDA, Pickering JA, Arthur MJP, Benyon RC. Human and rat hepatic stellate cells produce stem cell factor: a possible mechanism for mast cell recruitment in liver fibrosis. J Hepatol. 1999; 30:850-858.

55. Guo HR, Deng HD, Cui HM, Peng X, Fang J, Zuo ZC, Deng JL, Wang X, Wu BY, Chen KJ. Nickel chloride (NiCl2)-caused inflammatory responses via activation of NF- $\mathrm{KB}$ pathway and reduction of anti-inflammatory mediator expression in the kidney. Oncotarget. 2015; 6:28607-28620. doi: 10.18632/oncotarget.5759.

56. Livak KJ, Schmittgen TD. Analysis of relative gene expression data using real-time quantitative PCR and the 2- $\Delta \Delta$ CT method. Methods. 2001; 25:402-408. 